Maurer School of Law: Indiana University

Digital Repository@Maurer Law

Indiana Law Journal

Volume 92 | Issue 2

Article 5

Spring 2017

\title{
Post-Racialism and the End of Strict Scrutiny
}

David Schraub

University of California, Berkeley, dschraub@law.berkeley.edu

Follow this and additional works at: https://www.repository.law.indiana.edu/ilj

Part of the Constitutional Law Commons, Fourteenth Amendment Commons, Inequality and Stratification Commons, Law and Race Commons, and the Politics and Social Change Commons

\section{Recommended Citation}

Schraub, David (2017) "Post-Racialism and the End of Strict Scrutiny," Indiana Law Journal: Vol. 92 : Iss. 2, Article 5.

Available at: https://www.repository.law.indiana.edu/ilj/vol92/iss2/5

This Article is brought to you for free and open access by the Law School Journals at Digital Repository @ Maurer Law. It has been accepted for inclusion in Indiana Law Journal by an authorized editor of Digital Repository @ Maurer Law. For more information, please contact rvaughan@indiana.edu.

\section{$\Psi$}

JEROME HALL LAW LIBRARY

INDIANA UNIVERSITY

Maurer School of Law
Bloomington 


\title{
Post-Racialism and the End of Strict Scrutiny
}

\author{
DAVID SCHRAUB*
}

In recent years, a growing social consensus has emerged around the aspiration of a "post-racial" America: one where race is no longer a fault line for social strife or, perhaps, a morally significant trait whatsoever. This ambition, however, lies in tension with the most basic constitutional principle governing our treatment of race in the public sphere: that of "strict scrutiny." Post-racialism seeks to diminish the salience of race to near negligibility. The strict scrutiny of racial classifications, by contrast, significantly enhances the salience of race by treating it differently from virtually every other personal attribute or characteristic-including hair or eye color-extant in our society.

This Article examines both the emergence of post-racialism and the development of the strict scrutiny doctrine in an attempt to resolve the underlying conflict. Both the history of strict scrutiny and the conceptual underpinnings of post-racialism indicate that, under the right conditions, racial classifications should stop receiving this extraordinary standard of review. Yet advocates of post-racialism have not acknowledged that strict scrutiny should have an end date-much less articulated the conditions for what that end date might be. The use of strict scrutiny in perpetuity, mixed with its uneasy relationship to the post-racial ambition, creates a doctrine that is inherently self-defeating. A close look at what we mean by "post-racial," and how we have dealt with similar concerns in other sites of social conflict (for example, sex, religion, and indigenous status), can begin the necessary work of determining when and whether strict scrutiny should come to an end.

INTRODUCTION 600

I. TWO MODELS OF POST-RACIALISM 604

A. THE FIRST MODEL: MAKING RACE DISAPPEAR .....................................6 606

B. The SECOND Model: Normalizing RACE ...................................... 610

C. THE UNDERCURRENT: RACE AND FEAR .......................................... 614

II. POST-RACIALISM VERSUS STRICT SCRUTINY ............................................. 616

A. Post-Racialism Against CONTEMPORARy EQUAL PROTECTION DOCTRINE: PUTTING RACE ON THE CLOCK.......................................... 616

1. ACCESSING STRICT SCRUTINY ............................................... 617

2. APPLYING STRICT SCRUTINY .................................................. 620

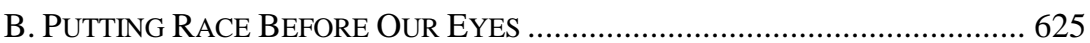

III. STRICT SCRUTINY IN A POST-RACIAL AMERICA............................................. 629

A. THE END OF STRICT SCRUTINY ...................................................... 630

1. RACE LiKe ANYTHING ElSE-PEREMPTORY STRIKES AND THE Strange CAREER of HEREDITARY PREFERENCES...................... 630

2. DIALING RACE BACK-ACCORDING RACE INTERMEDIATE SCRUTINY

* Senior Research Fellow, California Constitution Center, University of CaliforniaBerkeley Law School. Thanks to Patrick Barry, Josh Blackman, Kurt Lash, Sheldon Lyke, Marisa Maleck, Jud Mathews, Jillian Rodde, David Strauss, Chris Walsh, and innumerable conversants in the University of Illinois hallways for their feedback and support. 


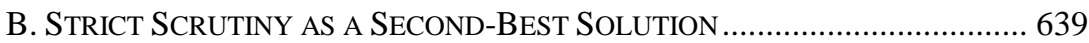

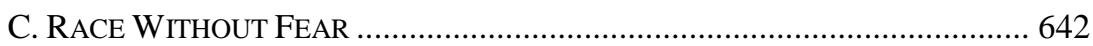

1. THE TRAILBLAZERS: RELIGION AND INDIGENOUS STATUS ............... 643

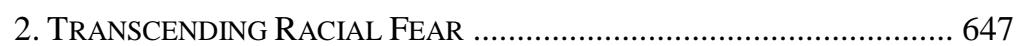

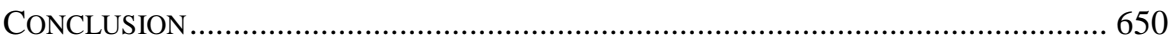

\section{INTRODUCTION}

One cannot talk about race in America without talking about "post-racial America." Whether the argument is presented as fait accompli (we are now a postracial society) or as an aspiration (we hope to eventually become a post-racial society), there is an emergent consensus around post-racialism as the governing metric of America's racial progression. This concept, in turn, has made its mark on American law. Chief Justice Roberts gave the standard formulation in Parents Involved in Community Schools v. Seattle School District No. 1 that "the way 'to achieve a system of determining admission to the public schools on a nonracial basis' is to stop assigning students on a racial basis. The way to stop discrimination on the basis of race is to stop discriminating on the basis of race." ${ }^{11}$ His was an implied retort to Justice Harry Blackmun's famous defense, in Regents of the University of California v. Bakke, of the use of race-conscious admissions decisions in public universities: namely, that "[i]n order to get beyond racism, we must first take account of race." "2 Though there is a sharp debate on the process, the end goal is clear: transcending America's deep history of racial conflict, discrimination, and injustice.

According strict scrutiny to racial classifications is generally assumed to be an adjunct to the desire to become post-racial. ${ }^{3}$ The logic is intuitive enough: strict scrutiny sharply reduces the instances where government can take note of race, and the less race is noticed, the more post-racial we are. But in reality, strict scrutiny is a policy that exists in deep tension with the post-racialist aspiration. Whereas postracialism seeks to diminish (and ultimately eradicate) the special salience of race as a political and social category, strict scrutiny provides for race's exceptional, indeed extraordinary, treatment. In contrast to nearly every other point of identity orientation - including those, such as hair or eye color, which we hold out as the "model" attributes we wish for race to emulate - any appearance of race in public

1. 551 U.S. 701, 748 (2007) (plurality opinion) (citation omitted) (quoting Brown v. Bd. of Educ., 349 U.S. 294, 300-01 (1955)); see also William Van Alstyne, Rites of Passage: Race, the Supreme Court, and the Constitution, 46 U. CHI. L. REV. 775, 809 (1979) ("[O]ne gets beyond racism by getting beyond it now: by a complete, resolute, and credible commitment never to tolerate in one's own life - or in the life or practices of one's government - the differential treatment of other human beings by race." (emphasis in original)).

2. 438 U.S. 265, 407 (1978) (opinion of Blackmun, J.); see also Kim Forde-Mazrui, The Constitutional Implications of Race-Neutral Affirmative Action, 88 GEO. L.J. 2331, 2397 (2000) ("The day when race no longer matters will not arrive until we take active measures, or affirmative action, to improve the conditions and remove the disadvantages that keep racial minorities down." (emphasis in original)).

3. See, e.g., Derrick Darby, Educational Inequality and the Science of Diversity in Grutter: A Lesson for the Reparations Debate in the Age of Obama, 57 KAN. L. REV. 755, 774 (2009) ("[A]ll uses of race must be subject to strict scrutiny in the post-racial era ...."). 
proceedings is subjected to the most exacting judicial scrutiny. ${ }^{4}$ In theory, this exceptional treatment should fall away as our society becomes less centered on race and racial conflict (that is to say, more "post-racial"). But the legal trend lines do not reflect this: as America moves away from de jure racial discrimination, strict scrutiny has become more, not less, entrenched. Increasingly, judicial application of strict scrutiny in the race context does more to heighten race's salience than it does to minimize racial tensions.

In other scholarship, ${ }^{5}$ I have argued that the concept of "perpetual suspect classes" is in conflict with the jurisprudential foundations of modern Fourteenth Amendment law. Strict scrutiny, as currently practiced, is doctrinally incoherent and normatively dangerous - doing more to further the subordination of putatively shielded groups than it gives back by way of judicial "protection." This Article extends that work into the broader social philosophy of race- - how we as a society envision our racial future and what strict scrutiny can and cannot do to take us there. "Post-racialism," as an aspiration, is considerably more complex than many of its proponents give it credit for; it does not necessarily imply a society in which race no longer matters. And no matter how one understands post-racialism as a concept, it is difficult to see how it could be operationalized under a judicial system that continues to devote specialized doctrinal attention to race and race alone. Far from conducting the path to a postracial future, strict scrutiny - the elevation of race to an exceptional role in American law-effectively guarantees we will not "get beyond" race.

The hesitance of antiracism activists to forthrightly attack strict scrutiny for racial classifications is understandable. The use of race in the public sphere has, for nearly all of American history, been inextricably tied to structures of power and domination - it has been the driving force behind immense human misery and inequality. The development of strict scrutiny doctrine was crucial in combatting these wrongs. But the reticence to move past strict scrutiny — other than by proposing failed half measures seeking to exempt "benign" racial classifications from the doctrine's ambit ${ }^{6}$ - has put progressives in an impossible situation. Conservatives have long since learned that they can achieve virtually all of their race-related policy objectives through mechanisms wholly compatible with strict scrutiny's demands. Moreover, they've successfully converted the historical link between race and power into a

4. Bakke, 438 U.S. at 291 (opinion of Powell, J.) ("Racial and ethnic distinctions of any sort are inherently suspect and thus call for the most exacting judicial examination.").

5. David Schraub, Unsuspecting, 96 B.U. L. Rev. 361, 363 (2016) [hereinafter Schraub, Unsuspecting]; cf. David Schraub, The Siren Song of Strict Scrutiny, 84 UMKC L. REV. 859 (2016) [hereinafter Schraub, Siren Song] (arguing that suspect classification of sexual orientation could do more harm than good).

6. See, e.g., Metro Broad., Inc. v. FCC, 497 U.S. 547, 564-65 (1990) (refusing to apply strict scrutiny to "benign race-conscious measures"), overruled by Adarand Constructors, Inc. v. Pena, 515 U.S. 200, 227 (1995); Kent Greenawalt, Judicial Scrutiny of "Benign” Racial Preference in Law School Admissions, 75 Colum. L. REV. 559, 575 (1975) (arguing that it would be a mistake to apply the normal strict-scrutiny approach to benign classifications); Darren Lenard Hutchinson, "Unexplainable on Grounds Other than Race": The Inversion of Privilege and Subordination in Equal Protection Jurisprudence, 2003 U. ILL. L. REV. 615, 691-93 (arguing that only caste-reinforcing racial classifications burden politically vulnerable groups and thus should be subjected to strict scrutiny). 
transcendent critique of any and all uses of race - sabotaging race-conscious progressive reform efforts. ${ }^{7}$ Today, strict scrutiny is almost exclusively deployed against progressive efforts to ameliorate racialized injustice. ${ }^{8}$ Having successfully enlisted strict scrutiny against progressive racial legislations, conservatives have managed to obscure the deep incoherency latent in their own program - a "post-racial" world in which race occupies a central, hallowed, and timeless place in constitutional jurisprudence.

There is a way out. One need not get beyond racism simply by eliminating race as a category. A coherent "post-racial" agenda could instead envision something more radical still: a world in which race no longer is a force of marginalization and exclusion. Instead of perpetually policing "dangerous" characteristics in the hopes that they disappear, this sort of post-racialism normalizes them-race is integrated into ordinary politics and society without being especially perilous or fraught. Instead of demanding erasure and assimilation, this vision of post-racialism is of "equality among socially and culturally differentiated groups, who mutually respect one another and affirm one another in their differences." 9 This understanding is less alien than it seems: it is, after all, already the main conception of religious equality. We overcome religious discrimination not by envisioning a world where "Jew" and "Muslim" disappear as categories but rather a world where Jews and Muslims and persons of all religious backgrounds can partake openly in democratic politics without fear that their identities will be leveraged against them or harnessed for oppressive ends.

It may seem strange to think of the end of racialized oppression as being a world in which race is simply a "normal" attribute of democratic politics - to be used or not as we please. But I suggest that this is the true apotheosis of equality. As a Jew, I enjoy a welter of protections under state and federal law protecting me from discrimination and animus. As a left-handed person, I possess none of these things. Yet there is no doubt I am more socially vulnerable as a Jew than as a lefty-the omission of "left-handedness" as a protected legal category reflects not marginalization but the absence of any systematic efforts to place that identity under serious threat. ${ }^{10}$ And so it is in general: true equality is not the existence of formal barriers against hurt or wrong - no matter how high or impregnable. Equality comes when equality is normal - so normal that you don't have to be perpetually on your guard to defend it. So normal that it wouldn't occur to anyone to try and take it away.

Following this introduction, this Article proceeds in three parts. In Part I, I explore

7. See Cheryl I. Harris, Whiteness as Property, 106 HARv. L. REv. 1707, 1768 (1993) (complaining that "at the very historical moment that race is infused with a perspective that reshapes it, through race-conscious remediation, into a potential weapon against subordination, official rules articulated in law deny that race matters" (emphasis in original)).

8. Schraub, Unsuspecting, supra note 5, at 392 (characterizing strict scrutiny as applying only to a "rump remainder" of racially inflected legislation).

9. Iris Marion Young, Justice AND the Politics of DifFerence 163 (1990).

10. Nor can the distinction be drawn on the basis that we never "use" left-handedness on a social basis. Nobody has a problem with a public university being sure to provide some lefthanded desks in the classroom or to make available a few left-handed golf clubs for rent. Lefties are not equal because society is "blind" to the category; they're equal because society can be trusted to deploy the category without tying it to a system of subordination. 
the concept of post-racialism. Post-racialism is a descriptive (or aspirational) claim about the salience of race in the public sphere-it describes the ends, not the means. The core of the post-racial instinct is a desire to transcend a racially stained past. The goal is to create an America which is not under the legacy of and does not risk replicating our history of racial oppression. But this ambition can be formulated in two ways. The standard account argues that a post-racial America is one where race has disappeared entirely, leaving no trace on American life or law. Yet there is also an alternative conception of post-racialism that envisions race as normalized-not carrying any special risk or peril compared to other human characteristics, leaving it up to individual persons and communities to determine whether it still possesses meaning or utility.

Part II explores the underlying tension between post-racialism and applying strict scrutiny to racial categorization. Doctrinally, there are a few narrowly delineated justifications for the usage of racial categories. But the standard reasons offered for preserving race-based strict scrutiny do not meet them - in this way, the justification for strict scrutiny collapses in on itself. Moreover, socially speaking there is ample reason to be skeptical that such a drastic and visible statement about race's continued importance is compatible with a nation that can honestly be said to have gotten "beyond race." Whatever post-racialism means, it surely cannot describe a society in which the full force and fury of the legal establishment stands ready to come crashing down at even the slightest whiff of race. In other words, in order to get beyond race, we must cease treating race as a special arena of judicial empowerment.

Finally, Part III explores three ways of resolving the paradox. The first is to abandon strict scrutiny entirely and truly treat race like eye or hair color. A "post-racial" jurisprudence of constitutional law would thus look dramatically different from that forwarded by the current Supreme Court majority. Even a jurisprudence where we began rolling racial scrutiny back - treating it more akin to sex (and thus giving it intermediate, rather than strict, scrutiny protection) —-would see some important doctrinal changes, most notably in the usage of "benign" racial classifications. The second is abandoning the dream of post-racialism. This may counsel the reemergence of race-conscious policy making, but then, it may not. The potency of the colorblindness principle, after all, is not necessarily dependent on it actually getting us beyond race. Race may always be with us; but it's entirely possible that colorblindness represents the best chance at mitigating the dangers associated with it. Abandoning post-racialism, in other words, doesn't prescribe a policy, but shifts the question from "how do we transcend race" to "how do we manage it."

The final option is that we rearticulate the meaning of post-racialism itself. Returning to the second model of post-racialism presented in Part I, I argue that the underlying motivator behind the post-racialism instinct is to get beyond the fear of race as a category - the paralyzing belief that any time race appears in our society, it necessarily is the harbinger of ethnic strife or the resurrection of Jim Crow. Colorblindness suppresses the demon, but it does not and cannot eradicate it. However, other options exist. For example, many defend a vision of "getting beyond" religious discrimination without demanding the total public suppression of religion as a category (indeed, such suppression would be seen as deeply hostile to our ideas of religious freedom). The goal of American race jurisprudence (and broader antiracism practice) should not be to suppress race but to enable the public appearance of race without the corresponding fear of hierarchy or domination. 
I wish to be very clear about the scope of my project. In articulating the vision of post-racialism that I do-where race is no longer a fraught identity feature laden by the omnipresent risk of hierarchy and subordination - I do not intend to suggest that we can achieve this ambition simply by force of will or through a few tweaks in our attitudes towards the proper role of race in society. Post-racialism, under my understanding or any other, will not be achieved "by proclamation alone." 11 The goal is rather to clarify what it is we are - or should be - pursuing when we say we want to be "post-racial," even if the ideal we settle upon feels quite distant. Just as Elizabeth Anderson asked, "What's the point of equality?", ${ }^{12}$ we should ask, "What's the point of post-racialism?" Answering that question does not itself bring us closer to the ideal, but it can clarify how our current practices are or are not viable as strategies for attaining it. And accordingly my critique of strict scrutiny stems not from a belief that we have achieved post-racialism but for the remnant artifact of the ancien régime, but rather from a concern that we remain quite far from a society where race ceases to be a site of fear and domination and that contemporary strict scrutiny doctrine is pushing us further away still.

\section{Two Models OF Post-RACIALISM}

What does post-racialism mean? Before we answer that, it is essential to answer a preliminary question: what sort of concept is post-racialism? ${ }^{13}$ In my view, postracialism is best understood as an aspiration, not a prescription. ${ }^{14}$ That is to say, postracialism is an answer to the question: "What should America look like with respect to race?" But it does not necessarily imply a particular strategy of how to get there (and, of course, it does not imply that we have already attained the aspiration). While many believe that a policy of strict colorblindness is the best route towards the goal of a post-racial society, others dissent from this outlook-for example, Justice

11. Cf. Kimberlé Williams Crenshaw, Race, Reform, and Retrenchment: Transformation and Legitimation in Antidiscrimination Law, 101 HARv. L. REv. 1331, 1347 (1988) ("Practically speaking, all companies can now be equal opportunity employers by proclamation alone. Society has embraced the rhetoric of equal opportunity without fulfilling its promise ....").

12. Elizabeth S. Anderson, What Is the Point of Equality?, 109 ETHICS 287 (1999).

13. Richard A. Wasserstrom, Philosophy and Social Issues: Five Studies 12-13 (1980) (distinguishing between four separate questions regarding the theoretical import of race: (1) the actual, current role race plays in American life (and our collective understandings regarding the same); (2) what causes or has caused this reality to emerge; (3) what the ideal state of affairs with respect to race in our society should be; and (4) what instrumentalities we ought to pursue in moving from the status quo to the ideal); Tommie Shelby, Racism, Moralism, and Social Criticism, 11 Du BoIs REv. 57, 57 (2014) (holding out four different articulations of what might be meant by post-racial, ranging from social scientific consensus that "race" is an incoherent concept to an "ironic[]" statement that it is no longer socially acceptable to criticize ongoing racist inequalities).

14. See Derrick Darby \& Argun Saatcioglu, Race, Justice, and Desegregation, 11 Du BoIs REv. 87, 93 (2014) ("The least controversial [interpretation of post-racialism] is that it expresses an aspiration regarding the kind of society we hope to become, namely one where a person's race does not constitute a barrier to equality of opportunity or to the fruits of citizenship."). 
Blackmun in Bakke. ${ }^{15}$ And, likewise, one can support colorblindness as a policy matter without any corresponding belief that it will necessarily lead to a post-racial world - for example, under the belief it is necessary to mitigate (though not transcend) racial strife and discrimination in a world in which race remains very relevant. ${ }^{16}$

This isn't to say that post-racialism and colorblindness are usually disconnected. Much the opposite: both are probably the dominant viewpoints in America within their respective domains - the orthodox view of racial jurisprudence (at least amongst American Whites) is to pursue a strategy of colorblindness to eventually reach a world in which race is irrelevant. But there is use in maintaining the conceptual distinction. The policies by which we pursue our ideals are not the same thing as the ideals themselves. And, as will be argued below, the doctrinal use of strict scrutiny with respect to race exists in deep tension with the ideal of post-racialism.

Within this descriptive framework, I forward two alternative conceptions of the meaning of post-racialism. One model, probably the dominant one, imagines a world where race is never used - where it, in effect, ceases to exist. This proposal aligns itself with the constitutional doctrine of colorblindness and strict scrutiny - both legalized efforts to drastically limit, if not obliterate, the usage of race in American life. A second conception of post-racialism runs orthogonal to this view. Though it, too, entails a dramatic reduction in the salience of race, it endeavors not to make race disappear but to make it like any other (nondangerous) characteristic extant in the populace. Race would no longer be special; it would no longer maintain its unique grip on the American psyche or American law. Under this view, doctrines like strict scrutiny are aberrational, for they maintain race's superordinate status in seeming perpetuity. But this view does not demand race never be used at all. The norm of democratic politics is precisely that the people are free to decide how to express their various identity characteristics in the public sphere and are likewise given substantial flexibility in determining when and how to use such characteristics as part of the political toolbox available for resolving social problems.

These concepts are in tension - but they share a unifying core. In both cases, the motivating instinct beyond the desire to be "post-racial" is a desire to neutralize the seeming peril and danger of race. Race is the source and subject of some of America's most grievous social sins. Americans of all backgrounds and politics wish

15. See supra note 2 and accompanying text; see also WASSERSTROM, supra note 13, at 51-77 (forwarding as the proper ideal with respect to race and sex a world in which both characteristics cease to be relevant but vigorously defending the justness and necessity of a system of racial and sexual preferential treatment as a means to that end); Alison Jaggar, On Sexual Equality, 84 ETHICS 275, 286 (1974) (observing that the belief that sexual separatism "is a necessary step on the way" to sexual equality does not, in and of itself, challenge the notion of "sexual integration as an ideal").

16. See, e.g., LAWrie BALfour, Evidence of Things Not SAid: JAmes BALDWIn AND the PROMISE OF AMERICAN DEMOCRACY 4 (2001) (arguing against heightening the public salience of race to combat racism because "[p]erhaps ... the subtler, subterranean forms of racism that lurk beneath the surface of public discourse ought to be left undisturbed. For what surfaces as frankness may simply be expressions of racism, formerly discredited, reemerging in a new guise."); infra notes 244-47 and accompanying text (arguing that Justice Thomas's views correspond to this position). 
not to replicate them and thus desire the creation of a racial state of affairs that - as greatly as possible_eliminates that risk.

\section{A. The First Model: Making Race Disappear}

In its simplest form, the first model of post-racialism appeals to the intuitive instinct that the easiest way for the problem of racism to go away would be for race to go away as well. ${ }^{17}$ The ideal of race is that it becomes something "invisible" or irrelevant, like hair or eye color. ${ }^{18}$ While, of course, discriminatory classification on the basis of race is offensive, the first model of post-racialism goes deeper to object to any government or social act that renders race salient. ${ }^{19}$

This idea of post-racialism is obviously heavily bound up with the strategy of colorblindness. Sumi Cho forwards that post-racialism is best understood as a proposed "retreat from race." 20 This retreat, she argues, diminishes several aspects of contemporary civil rights practice: it eliminates race-based material-support programs like affirmative action, refuses to grant special normative status to how people of color conceptualize the current state of racial affairs and what is needed to achieve racial justice, and rejects race as a valid focal point for collective political action. ${ }^{21}$ Just as it would be strange (to say the least) for programs or political behavior to focus or center around the color of one's hair, we're told, it is equally unsupportable to center them around the color of one's skin.

The analogy to such visible but morally innocuous attributes like eye color, or the first letter of one's last name, is compelling. ${ }^{22}$ As the Supreme Court put it in Miller v. Johnson, the very essence of the American social compact is that "the Government must treat citizens 'as individuals, not "as simply components of a racial, religious,

17. john a. powell, Post-Racialism or Targeted Universalism?, 86 DENV. U. L. REV. 785, 789 (2009) (conceding the "intuitive logic to this assumption" while arguing that "it turns out ... often clearly wrong").

18. WASSERSTROM, supra note 13, at 24 ("[O]ne conception of a nonracist society ... would be one in which the race of an individual would be the functional equivalent of the eye color of individuals in our society today."); R. Richard Banks, Jennifer L. Eberhardt \& Lee Ross, Discrimination and Implicit Bias in a Racially Unequal Society, 94 CALIF. L. REV. 1169, 1171 (2006) ("[T]he most straightforward account [of what it means to be racially unbiased] would require one to accord race no more significance than, say, eye or hair color . . ..”).

19. See, e.g., Alexander M. Bickel, The Morality of Consent 133 (1975) (objecting to the use of racial quotas "in a society desperately striving for an equality that will make race irrelevant"); R. Richard Banks, "Nondiscriminatory” Perpetuation of Racial Subordination, 76 B.U. L. REV. 669, 690 (1996) (book review) ("If race is morally irrelevant, the individuals who constitute a morally upright society and that society's state apparatus should both be colorblind. The moral ideal of colorblindness thus embodies the vision of a colorblind state as well as a colorblind society.").

20. Sumi Cho, Post-Racialism, 94 Iowa L. Rev. 1589, 1593-94 (2009) (citing Dana Y. TAKagi, The Retreat from Race: Asian-American Admissions And RaCial Politics (1992)).

21. Id. at 1594-97.

22. David Strauss, The Myth of Colorblindness, 1986 SuP. CT. REv. 99, 117 (conceding that "[t]here is enormous appeal to the ideal of a society in which race is as insignificant a factor as eye color"). 
sexual or national class." ${ }^{\prime 23}$ The idea that anything of significance should turn upon something as morally arbitrary as skin color is as absurd as it turning on any other fluke of phenotype. While at present race may still have a social significance that requires its (limited) use in governmental programs, this is a temporary state of affairs - a concession to a historical evil that (hopefully soon) will be vanquished for good. ${ }^{24}$ Given that the American categories of race have little (if any) biological basis, ${ }^{25}$ what utility is there in permanently preserving race as a category at all? In this model of post-racialism, there is none.

Consider the Seattle desegregation program struck down in Parents Involved in Community Schools v. Seattle School District No. $1 .{ }^{26}$ Seattle generally allowed pupils to enroll in whichever school within the district they wished; however, for schools that were oversubscribed, the district considered integration concerns as a "tiebreaker." 27 For oversubscribed schools whose racial composition had strayed from the overall district demographics, the district's tiebreaker "selects for assignment students whose race "will serve to bring the school into balance." 28 If the school was predominantly White (as was the case in three high schools), this would favor non-White applicants; if the school was predominantly non-White (as was the case in one high school), this would favor White applicants. ${ }^{29}$ And if a school's enrollment was in line with the district's overall demographics (as was the case in one high school), neither race would be favored. ${ }^{30}$

Seattle's program did not intrinsically favor one race-it was not racially "discriminatory" in the classic sense, even "benignly" so. ${ }^{31}$ It did not, for example, say that because African Americans had faced a history of discrimination, they would be given general preference over White students in the event a school was oversubscribed..$^{32}$ Nor did it cause the admission of less-qualified applicants over more-

23. 515 U.S. 900, 911 (1995) (quoting Metro Broad., Inc. v. FCC, 497 U.S. 547, 602 (1990) (O’Connor, J., dissenting)).

24. See infra note 110.

25. K. Anthony Appiah, Race, Culture, Identity: Misunderstood Connections, in CoLOR Conscious: The Political Morality of Race 30, 73 (K. Anthony Appiah \& Amy Gutmann eds., 1996) ("I have no problem with people who want to use the word 'race' in population genetics... . The trouble is that ... while there are human populations that are and have been for some time relatively reproductively isolated, it is not at all plausible to claim that any social subgroup in the United States is such a population.”).

26. 551 U.S. 701 (2007).

27. Id. at $711-12$.

28. Id. at 712 (quoting the record).

29. Id. at 713 .

30. Id.

31. A "benign" racial classification is one that favors a disadvantaged racial minority for seemingly salutary purposes - for example, political inclusion or compensation for social discrimination. While at one point these classifications received only intermediate scrutiny, Metro Broad., Inc. v. FCC, 497 U.S. 547, 564-65 \& n.12 (1990), now they are treated as identical to racial classifications which are designed to promote inequality, Adarand Constructors, Inc. v. Pena, 515 U.S. 200, 227 (1995).

32. Cf. Grutter v. Bollinger, 539 U.S. 306, 320 (2003) (noting that racial minorities were given a relatively large, though not decisive, preference in a competitive admission environment); Regents of the Univ. of Cal. v. Bakke, 438 U.S. 265, 289 (1978) (opinion of Powell, 
qualified competitors (as enrollment decisions in Seattle are not meant to be evaluations of students" "merit"). ${ }^{33}$ And it expressed favoritism towards neither White nor non-White students, though of course in the context of individual schools either might end up being in a favored or disfavored position. The program was, in the words of the Washington Supreme Court, "race-cognizant but racially neutral." ${ }^{34}$ Yet the U.S. Supreme Court still applied strict scrutiny ${ }^{35}$ and still ruled the program unlawful. ${ }^{36}$

From the vantage of contemporary Supreme Court doctrine, however, Washington's formulation of "race-cognizant but racially neutral" is incomprehensible gibberish. Any race-conscious governmental act is inherently ra-

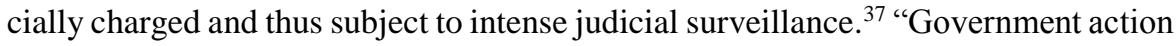
dividing us by race is inherently suspect because such classifications promote "notions of racial inferiority and lead to a politics of racial hostility." 38 The very act of using race — even in manners that appear facially nondiscriminatory - is itself morally and socially pernicious. ${ }^{39}$ This theme was also present in Justice Kennedy's concurrence, which expressed considerable concern at the negative effects of being "forced to live under a state-mandated racial label." 40 The Court's rhetoric seems intentionally agnostic towards how race is used - the problem and the danger is that race is used at all. More importantly, its objection seems to be both one of ends as well as means: It is not simply the case that the Court predicts race-conscious political programs will lead to racial strife. It is that it sees something inherently degrading in race being a salient player in American life at all. ${ }^{41}$

The Supreme Court is hardly the only political institution to adopt this outlook.

J.) (striking down a quota program which restricted White applicants to competing for " 84 seats in the entering class, rather than the 100 open to minority applicants")

33. See Parents Involved in Cmty. Sch. v. Seattle Sch. Dist., No. 1, 72 P.3d 151, 166 (Wash. 2003) (en banc), rev'd, 551 U.S. 701 (2007); Parents Involved, 551 U.S. at 834 (Breyer, J., dissenting) (noting that the challenged programs "do not seek to award a scarce commodity on the basis of merit, for they are not magnet schools; rather, by design and in practice, they offer substantially equivalent academic programs and electives").

34. Parents Involved, 72 P.3d at 156 (parentheses omitted).

35. Parents Involved, 551 U.S. at 720 ("It is well established that when the government distributes burdens or benefits on the basis of individual racial classifications, that action is reviewed under strict scrutiny.").

36. Id. at 748 .

37. Adarand Constructors, Inc. v. Pena, 515 U.S. 200, 227 (1995) (demanding the application of strict scrutiny to "all governmental action based on race" (emphasis added)).

38. Parents Involved, 551 U.S. at 746 (plurality opinion) (quoting City of Richmond v. J.A. Croson Co., 488 U.S. 469, 493 (1989) (plurality opinion)).

39. Id. at 745-46 ("[D]istinctions between citizens solely because of their ancestry are by their very nature odious to a free people whose institutions are founded upon the doctrine of equality." (alteration in original) (quoting Adarand, 515 U.S. at 214)).

40. Id. at 797 (Kennedy, J., concurring in part and concurring in the judgment).

41. Id. at 752 (Thomas, J., concurring) ("[E]very time the government places citizens on racial registers and makes race relevant to the provision of burdens or benefits, it demeans us all.” (quoting Grutter v. Bollinger, 539 U.S. 306, 253 (2003) (Thomas, J., concurring in part and dissenting in part))). 
Take the recent Arizona statute ${ }^{42}$ targeting high school ethnic studies programs, resulting in the termination of Tucson's Mexican Studies class and the banning of books where "race, ethnicity and oppression are central themes." ${ }^{43}$ Though such courses are obviously race-conscious (as race and ethnicity are their explicit subject matter), they do not in and of themselves discriminate between races or treat one race differently than another. But, opponents argue, simply raising race as an important issue is enough: by priming students to think of themselves in racial terms, such programs create "groupthink" and stoke racial division where none (they claim) had existed before. ${ }^{44}$ The state school superintendent thus argued that ethnic studies programs, as a whole, "are designed to promote ethnic chauvinism" and are inherently inconsistent with America's individualist ethos ${ }^{45}$ Post-racialism, understood in this way, has no place for race playing any role in American public life-regardless of who, how, or what it is being used for-because the usage of race itself is the problem we are trying to get beyond. ${ }^{46}$

It is important to disentangle two distinct positions that could be being forwarded here. The first is simply that of contemporary prescription. The general prohibition on the usage of race is an assessment that, given the current state of affairs with respect to race, our society cannot maintain any semblance of equal opportunity or racial harmony if race is allowed into the picture. But, in another context where circumstances are different, that might not be true - a society where racial tensions had

42. ARIZ. ReV. StAT. ANN. § 15-112(A) (2014) (prohibiting courses which, among other things, are "designed primarily for pupils of a particular ethnic group" or which "[a]dvocate ethnic solidarity instead of the treatment of pupils as individuals"), invalidated in part by Arce v. Douglas, 793 F.3d 968 (9th Cir. 2015). In 2015, the Ninth Circuit reinstated a legal challenge to the statute asserting that it violated the First and Fourteenth Amendments. Arce, 793 F.3d at 990 .

43. Jeff Biggers, Who's Afraid of "The Tempest"?, SAlON (Jan. 13, 2012, 10:47 PM), http://www.salon.com/2012/01/13/whos_afraid_of_the_tempest/ [https://perma.cc/X2AV-LVEH]. The banned books ranged from Paulo Freire's Pedagogy of the Oppressed to Shakespeare's The Tempest. Id.

44. See, e.g., Stephen Ceasar, Tucson Students Confront Loss of Their Chicano Studies Class, L.A. TIMES (Jan. 11, 2012), http://articles.latimes.com/2012/jan/11/nation/la-na-ethnic -studies-20120112 [https://perma.cc/C3EC-C3ZX] (citing objections that the program "promotes groupthink and victimhood"); Mark Lacey, Rift in Arizona as Latino Class Is Found Illegal, N.Y. TiMES (Jan. 7, 2011), http://www.nytimes.com/2011/01/08/us/08ethnic.html [https://perma.cc/Y6MZ-64BA] (citing one teacher as claiming that "[o]n the first day of school, they are no different than students in any other classes . . . But once they get told day after day that they are being victimized, they become angry and resentful").

45. Arizona Legislature Passes Bill To Curb 'Chauvanism' in Ethnic Studies Programs, Fox NEws (Apr. 30, 2010), http://www.foxnews.com/politics/2010/04/30/arizona-legislature -passes-banning-ethnic-studies-programs.html [https://perma.cc/828A-5LU5] (quoting state school superintendent Tom Horne).

46. See Cynthia V. Ward, Commentary, The Limits of "Liberal Republicanism": Why Group-Based Remedies and Republican Citizenship Don't Mix, 91 Colum. L. Rev. 581, 606 (1991) (arguing generally that interest-group pluralism on race or sex lines is "communopathic," destroying the capacity of the polity to engage in collective problem solving while attuned to the needs and interests of all and instead fostering - even demanding - the view that disparate groups are locked in a perpetual state of provincial political warfare). 
seriously receded or where race was not considered a major point of conflict may well be able to tolerate certain public uses of race without there being any problem at all. It is a discussion over means, not ends. ${ }^{47}$

But it seems like the proponents of the first model are often making a more expansive claim about the type of society we should aspire to be. ${ }^{48}$ When they talk about the inherent indignity of being sorted into a racial category, ${ }^{49}$ or the necessarily "chauvinistic" character of a focus on questions of race or ethnicity, ${ }^{50}$ they are talking not just of process but of end goals. They are not just promoting, as a provisional tactical matter, policies and doctrines that limit the use of race. They aspire to a world where race effectively no longer exists - where it is as if race never "happened." 51

The problem is that - appealing or not - this vision may not be translatable into a legal doctrine. After all, this view of race-where it is effectively exiled from every nook and cranny of American society-cannot countenance any use of race, including those necessary to instantiate legal doctrines such as strict scrutiny. ${ }^{52}$ Maintaining a system of government-mandated colorblindness requires a relatively thick social conception of race (else how would we know what is prohibited?) and a constant state of public vigilance to guard against the (re)infection of race thinking. This stands in stark contradiction to a world where race has, in fact, disappeared from view entirely.

This is not to say such a vision is entirely untenable. Indeed, below I will offer a model of an identity characteristic that once was considered a serious social danger in America but has since faded to obscurity.$^{53}$ Rather, the point is that this vision necessitates a severely circumscribed legal role - it requires us to at least contemplate "the end of strict scrutiny." If the strong arm of the law is indefinitely necessary to maintain this sort of post-racialism, then it cannot be said that race has actually disappeared.

\section{B. The Second Model: Normalizing Race}

While the promise of making race disappear has considerable force, it is not the only response Americans have been able to imagine with respect to historically dangerous identities. Another way of conceptualizing post-racialism is not as a world

47. See infra Part III.B (defending perpetual use of strict scrutiny in a world where racial conflict is admitted to be an inalterable fact of the American social sphere).

48. See supra notes 13-16 and accompanying text (arguing that post-racialism is an aspiration, not a prescription).

49. See supra notes $37-41$ and accompanying text.

50. See supra notes $42-45$ and accompanying text.

51. Tamotsu Shibutani \& Kian M. Kwan, Ethnic Stratification: A Comparative APPROACH 589 (1965) (arguing that "it is only a matter of time before a more enlightened citizenry" recognizes that ethnic identity is a fiction and "will become a thing of the past"); see also Michael Walzer, Preface to Jean-Paul Sartre, Anti-Semite And Jew, at v, xx (George J. Becker trans., 1995) (describing Sartre's long-term vision as a "society where groups no longer exist to be oppressed and marginalized").

52. See infra Part II.

53. See infra Part III.A.1 (discussing the trajectory of how questions of hereditary privileges and preferences are treated in American law and society). 
without race but as a world in which race is normalized - just another facet of human identity, without distinctive legal treatment or presumed social peril.

The analogy to hair or eye color is illustrative here as well. In most places and across the broader spectrum of American constitutional law, race and physical appearance (or other qualities we think of as exemplifying "benign" characteristics) are treated nothing alike. ${ }^{54}$ Race-conscious policies are subjected to strict scrutiny-the most searching and stringent inquiry in American constitutional law. Eye color, by contrast, is not a protected class at all - a law distinguishing on the basis of eye color would face only the extremely relaxed hurdle of overcoming rational basis scrutiny. A person with no knowledge of our history with racial discrimination-someone who truly did see race and eye color as equally (un)important - would be baffled by the immense difference in how contemporary antidiscrimination law treats the two categories ${ }^{55}$ And, despite the ubiquity of claiming that race ought to be as relevant as any other phenotype, claims that we should actually treat them legally alike-in other words, that discrimination based on appearance should gain the full force and protection of our antidiscrimination doctrines - are typically met with derision. ${ }^{56}$

There are near-infinite bases upon which the government can elect to classify, and the vast majority of them are subjected to only a minimal, "rational basis" review. ${ }^{57}$ Race is treated differently for perfectly sensible reasons: the unique historical salience of racial discrimination in particular renders it trivializing to say that discrimination on the basis of eye color is of an equivalent moral gravity to a form of discrimination that has manifested in slavery, in segregated social spaces, and in lynch mobs. ${ }^{58}$ The past (and present) prevalence of racial bigotry and prejudice conjure

54. See Deborah L. Rhode, The Beauty Bias: The Injustice of Appearance in Life AND LAW 125-34 (2010) (canvassing the limited number of American jurisdictions which have passed laws restricting appearance-based discrimination).

55. Strauss, supra note 22, at 112 (observing that "the truly colorblind actor, the proverbial person from Mars to whom racial discrimination is a totally alien concept" would find incomprehensible the difference in how we treat race versus eye color).

56. See, e.g., Richard Thompson Ford, The Race CARD 159 (2008) (dismissing the necessity of anti-discrimination laws targeting weight, attractiveness, or physical appearance); WaLter Olson, SchOOLS FOR MisRule: Legal ACADEMIA AND AN OvERLAWYERED AMERICA 5 (2011) (mocking academic efforts to more robustly combat "appearance-based discrimination"); AnNe Phillips, The Politics of Presence 46 (1995) (noting the "slippery slope which stretches from ... ethnic minorities ... to take in . . people with blue eyes and red hair").

Even writers who agree that appearance-based discrimination is a real and serious phenomenon are skeptical of adopting legal prohibitions akin to race-discrimination doctrine. See Enbar Toledano, May the Best (Looking) Man Win: The Unconscious Role of Attractiveness in Employment Decisions, CoRNELl HR ReV., Feb. 14, 2013, at 9, http://digitalcommons.ilr .cornell.edu/cgi/viewcontent.cgi?article=1045\&context=chrr [https://perma.cc/93BW-7FV8] (noting the wide body of research supporting the presence of discrimination based on attractiveness, but concluding that rendering "such judgments illegal would... prove unreasonable and ineffective").

57. See infra notes 79-85 and accompanying text.

58. See, e.g., Mario L. Barnes, Erwin Chemerinsky \& Trina Jones, A Post-Race Equal Protection?, 98 GEO. L.J. 967, 977 (2010) (noting that the past use of racial categories has "hardened consequences"); Girardeau A. Spann, Affirmative Action and Discrimination, 39 How. L.J. 1, 42 (1995) ("[T] he long history of the disadvantages suffered by racial minorities 
"special fears that [racial classifications] are motivated by an invidious purpose." 59 Meanwhile, for better or for worse, our identities are considerably more bound up in racial categories than they are in eye-color categories, and that necessitates a more wary approach to grappling with racial discrimination than discrimination on the basis of appearance. ${ }^{60}$

Under this view, we know race remains a problem precisely because it resists retreating back into its superficial unimportance. Consider a typical method for quickly sorting large groups of people: the use of the first letter of their last name. This, of course, is not considered particularly controversial. Nor does it signal that we as a society are particularly "conscious" of how our names our spelled. Much the opposite - the ability to use this sorting mechanism is possible precisely because alphabetical order is exceedingly unimportant - it is a normal, unremarkable part of our life, one which occasionally turns out to have bearing on social organization and interaction. Meanwhile, all persons might agree that the color of my skin is no more morally relevant than the fact that my last name begins with the letter $S$. Yet we very much see a difference between being sorted into the "M-Z" line at the DMV compared to the DMV creating (literal) race lines. This distinction in social meaning comes from the knowledge that race still has a great deal of salience; thus, the category cannot be used wholly innocuously. It always conjures up a sense of peril and danger, even in situations where conceptually analogous criteria could be used with little concern.

The aspiration of a second-model post-racial world would be one in which these characteristics no longer attach to race. The normalization of race would represent a world in which the seemingly unique peril that surrounds race will have faded away. In such a world, people may choose to reference, associate around, or otherwise make use of race - or they may not. Unlike the first model of post-racialism, which seeks to utterly annihilate racial difference, the second model follows Theodor Adorno's recommendation to pursue not "a unitary state, but the realization of universality in the reconciliation of differences." ${ }^{\circ 1}$ The point is that because race became just like any other characteristic - no more or no less dangerous - it likewise became anachronistic (if not counterproductive) to subject it to special rules and restrictions.

This perspective is not limited to characteristics that lack a significant history of prejudice and oppression tied to their name. Consider religion, gender, or sexual orientation. Religion is an obvious example of an identity towards which pluralism is often defended as a qualitatively superior response to the problems of discrimination

in the United States . . is what accounts for the cultural significance of race, and it is what makes race different from eye color or hair color."); James Lileks, Equality for the, Uh, Different, STAR TRIB. (Minneapolis), Jan. 19, 1992, at 25A (arguing, in the context of a proposed Santa Cruz ordinance which would bar discrimination based on appearance, that the law "puts hair color and skin color on the same moral plane").

59. Johnson v. California, 543 U.S. 499, 505 (2005).

60. WASSERSTROM, supra note 13, at 14-15 (observing that, while one can imagine a society in which race, like eye color, was simply a matter of superficial physiology, the particular social and cultural history of race in our society prevents us from simply incorporating our hypothetical treatment of eye-color difference into the race context).

61. Theodor Adorno, Minima Moralia: Reflections on a Damaged Life 103 (E.F.N. Jephcott trans., Verso 2005) (1951). 
and bigotry. The goal of religious-equality advocates is almost never to eliminate religious difference; rather, it is to create conditions where religious difference can be expressed and preserved without resulting in any hostile treatment or discrimination. Sometimes, this is a simple, pragmatic calculation that the costs of creating religious orthodoxy (or eliminating religion altogether) are not worth the amount of conflict it would provoke. ${ }^{62}$ For others, religious pluralism itself might be considered valuable and good. ${ }^{63}$ With respect to sex, there has been a significant debate as to whether sex difference is something to be valued or disposed of, with both "left" and "right" theorists present on both sides of the divide. ${ }^{64}$ The greater willingness in society and the courts to accept at least the possibility of sex difference gave women's advocates considerably more flexibility in promoting sex-discrimination doctrines that went beyond formal-equality models ${ }^{65}$ And sexual orientation might present the clearest case of all, with Andrew Sullivan's landmark call for gay rights holding forth a world wherein gay and lesbian identity is present but entirely normalized, no longer considered to be exceptional or aberrant. ${ }^{66}$

62. WASSERSTROM, supra note 13, at 27 (asserting that even those who might prefer a unitary state of religious affairs might still believe "that the evils of achieving anything like homogeneity far outweighed the possible benefits"); Brian Leiter, Why Tolerate Religion?, 25 CONST. Comment. 1, 3 (2008) (noting the "Hobbesian" case for permitting religious heterodoxy - that the costs of religious warfare render it unfeasible to impose a single, orthodox view on the matter).

63. See WASSERSTROM, supra note 13, at 27; Michael W. McConnell, Free Exercise Revisionism and the Smith Decision, 57 U. CHI. L. REV. 1109, 1139 (1990) ("The ideal of free exercise of religion ... is that people of different religious convictions are different and that those differences are precious and must not be disturbed. ... The ideal of free exercise is counter-assimilationist; it strives to allow individuals of different religious faiths to maintain their differences in the face of powerful pressures to conform."). Wasserstrom and McConnell contrast this perspective to how we ought to view race, but of course this is precisely the nature of the dispute itself. See id. at 1139 \& n.132; supra note 15.

64. See Jaggar, supra note 15, at 276-77 (recounting the traditional feminist viewpoint that a "nonsexist society is one which is totally integrated sexually, one in which sexual differences have ceased to be a matter of public concern," while noting the growing challenge to this perspective from within the feminist movement). Within Christian and particularly Catholic feminist thought, a "new feminism" that seeks to note the complementarity, rather than the interchangeability, of the sexes has emerged as an important statement regarding what (in the view of the Church) sex equality means. See generally WOMEN IN CHRIST: TOWARD A New FEminism (Michele M. Schumacher ed., 2004). Christina Hoff Sommers is probably the most prominent theorist identified broadly with the "right" who promotes a "sex-blind" conception of sexual equality. See Christina Hoff Sommers, Who Stole Feminism?: How Women Have Betrayed Women 22 (1994) (attacking what she refers to as "gender feminism" as lacking grassroots support and being divorced from the original, "First Wave" feminist movement which concentrated on securing formal equality to men).

65. Serena Mayeri, Reasoning from Race: Feminism, Law, And the Civil Rights REVOLUTION 229 (2011) ("Paradoxically, sex equality law became a promising template in part because the perception that men and women were inherently different meant that many judges did not see formal equality as an option. ... [F]eminists persuaded the Court to distinguish between ... 'invidious' classifications and 'genuine affirmative action' [and] used [these] principles to combat the rise of colorblindness.").

66. Andrew Sullivan, Virtually Normal: An Argument About Homosexuality 
The "sex-conscious" or "religion-conscious" advocates certainly do not want to perpetuate a system where religious minorities or women are subjected to the sort of bigotry and hostility that has been too characteristic of global history. But they likewise do not feel that they should have to drop their distinctive religious or sexual identities to be accepted as equal. ${ }^{67}$ What they want is the ability to be distinctively female or gay or Jewish or Buddhist (or what have you) as a normal, unremarkable part of daily life. ${ }^{68}$ Equality as normality envisions a time-perhaps a quite distant time - when a given identity, historically the site of significant oppression and marginalization, is able to enter into public life openly, fearlessly, and on equal terms as all others.

\section{The Undercurrent: Race and Fear}

Clearly, these two models of post-racialism are in tension with one another. ${ }^{69}$ But they also share a motivating commonality. Post-racialism is best understood as a desire to transcend a racially stained past. This is what motivates so many people to demand such a radical shift in the role race plays on the American political terrain. Most White Americans retain some degree of shame for our collective racial past yet do not wish to be haunted by it forever. ${ }^{70}$ Post-racialism offers a vision of a new beginning for America, one freed of this toxic legacy. And viewed within this context, those who persist in utilizing race as a category are seen as barriers-holding America back from reaching this new and more "enlightened" stage of our national

(1995). The classic retort to this came in Michael WARner, The Trouble With Normal (1999), but Warner's argument was, of course, not that gayness should disappear but that it should maintain its unique, differentiated character vis-à-vis heterosexuality. A true parallel to first-model post-racialism would be difficult to find in a gay-rights context (as it borders precariously on conservative claims that homosexuality is a false and abhorrent identity), but perhaps the closest analogue would be in calls by some activists to abolish sexual orientation entirely in favor of a sexual outlook that is entirely fluid and not bound by rigid categorization. See Jamie Heckert, Resisting Orientation: On the Complexities of Desire and the Limits of Identity Politics (2005) (unpublished Ph.D. dissertation, University of Edinburgh) (on file with the Indiana Law Journal).

67. See, e.g., PhilliPs, supra note 56, at 8 ("Women do not want to change their sex, or black people the colour of their skin, as a condition for equal citizenship; nor do they want their differences discounted in an assimilationist imposition of 'sameness'.").

68. As Catharine MacKinnon notes, one cannot truly know what it is to be a woman while still laboring against omnipresent sexual domination. CATHARINE A. MACKinnOn, Feminism UNMODIFIED 45 (1987) ("Take your foot off our necks, then we will hear in what tongues women speak.").

69. Though, notably, the second model may be a way station to the first. In a world where individuals and communities can elect to use race free of concerns that it is an inevitable harbinger of doom, it is still entirely plausible they will simply elect not to. They might decide race is not an important or meaningful concept in their lives and let it lapse. That sort of world would look substantively identical to the sort of world envisioned in the first model of postracialism.

70. Barnes et al., supra note 58, at 976 ("Many Americans are tired of having to deal with race and embracing post-racialism frees at least white Americans from this 'burden."'). 
development. ${ }^{71}$ By contrast, post-racialism promises moral absolution for our racially corrupt past. If race is America's original sin, post-racialism offers out a virgin rebirth. $^{72}$

This sentiment is hardly new. As Darren Lenard Hutchinson compellingly documents, a collective sense of "exhaustion" towards dealing with race and racial topics has been a pervasive theme across our history, emerging at least as early as Reconstruction and reappearing in virtually every major social controversy related to race since. ${ }^{73}$ Its ubiquity creates legitimate grounds for skepticism with regards to its descriptive accuracy - to the extent that post-racial themes could be deployed as early as the 1866 debate over the Freedman's Bureau, it is evident that the claim of post-racialism need bear no relationship to its reality. ${ }^{74}$ It is highly likely that many invocations of America as having successfully become "post-racial" are the racism equivalent of George Aiken's (apocryphal) suggestion for extracting America from the Vietnam $\mathrm{War}^{75}$ : declare victory and go home. But the prevalence and staying power of post-racial language does reveal its strong hold on America as an aspiration.

Yet descriptive jumping-the-gun notwithstanding, the desire to attain such a world is not illegitimate. ${ }^{76}$ Skin color is essentially morally arbitrary, yet when imbued with an ideology of superiority and inferiority it can become extraordinarily dangerous. ${ }^{77}$ Having experienced this moral catastrophe, we are right to be fearful of it. Stripping

71. Id. (observing that, from the post-racialist mindset, those who oppose affirmative action and other like policies are "the ones who have moved on to a new, more enlightened era, while those who are trying to continue race-conscious remedies are mired in the past").

72. Douglas Kmiec characterizes the controversy in precisely these terms: a world where race is not publicly considered is a "society without sin." Douglas W. Kmiec, Foreword, The Abolition of Public Racial Preference-An Invitation to Private Racial Sensitivity, 11 NOTRE DAME J.L. ETHICS \& Pub. Pol’y 1, 13 (1997).

73. Darren Lenard Hutchinson, Racial Exhaustion, 86 WASH. U. L. REV. 917 (2009).

74. See id. at 931-38 (documenting congressional and executive opposition to the Bureau, which was framed as a special privilege for Black citizens that was unfair and unnecessary in the supposedly equal playing field established postemancipation); see also The Civil Rights Cases, 109 U.S. 3, 25 (1883) ("When a man has emerged from slavery, and by the aid of beneficent legislation has shaken off the inseparable concomitants of that state, there must be some stage in the progress of his elevation when he takes the rank of a mere citizen, and ceases to be the special favorite of the laws ....").

75. This instinct, of course, is what Crenshaw referred to in deriding those who think we can transcend racism "by proclamation alone." Crenshaw, supra note 11, at 1347.

76. The problem is that, while people do suffer from a sense of cognitive dissonance when faced with injustice, they adopt the path of least resistance in resolving it. In situations where actually remedying the injustice itself is difficult or complicated, persons tend to simply redefine the underlying dynamic in ways that are consistent with their belief in a "just world." See Jon Hanson \& Kathleen Hanson, The Blame Frame: Justifying (Racial) Injustice in America, 41 HARV. C.R.-C.L. L. Rev. 413, 419-20 (2006) (citing Melvin J. Lerner \& Carolyn H. Simmons, Observer's Reaction to the "Innocent Victim": Compassion or Rejection?, $4 \mathrm{~J}$. PERSONALITY \& Soc. PsychOL. 203 (1966)).

77. See Greta McMorris, Comment, Critical Race Theory, Cognitive Psychology, and the Social Meaning of Race: Why Individualism Will Not Solve Racism, 67 UMKC L. REV. 695, 705 (1999) (noting that "[s]kin color is about as arbitrary as eye color," and children informed that their eye color makes them superior or inferior will begin to exhibit predictable behavioral reactions). 
that sense of danger from race-returning it to a state of moral negligibility-offers a prospect of relief from centuries of severe social conflict. And that would undoubtedly be a good thing. Post-racialism - in either the first or second conception - holds appeal precisely because it offers a way out of a world where one of America's most long-standing points of social cleavage has been healed. It is valid and necessary to resist those who wish to attain such victory by "proclamation alone," ${ }^{78}$ but the aspiration itself is a perfectly reasonable one.

\section{POST-RACIALISM VERSUS STRICT SCRUTINY}

Contrary to what is commonly assumed, the application of strict scrutiny to racial classifications is in deep tension with the idea of post-racialism. Whereas postracialism seeks to minimize race's salience, strict scrutiny is by its terms an extraordinary usage of race, one that separates it out from virtually every other classification (including those we wish for race to emulate). ${ }^{79}$ The problem is both conceptual as well as specific to the particular doctrinal rules which have emerged sharply limiting the contexts in which race can legitimately be used. Doctrinally speaking, there is a deep contradiction between the Supreme Court's limited carve-outs for when race can be used and the characteristics of post-racialism. And more broadly, it is selfdefeating to aspire to get beyond race while simultaneously meeting any public appearance of race with the full fury of American constitutional law.

\section{A. Post-Racialism Against Contemporary Equal Protection Doctrine: Putting Race on the Clock}

Constitutionally speaking, race is most associated with the Fourteenth Amendment's guarantee of equal protection. ${ }^{80}$ The Supreme Court has divided its equal-protection analysis, with most classifications receiving a minimal rational basis review ${ }^{81}$ and a few "suspect classifications" being subject instead to either

78. Crenshaw, supra note 11 , at 1347.

79. See San Antonio Indep. Sch. Dist. v. Rodriguez, 411 U.S. 1, 28 (1973) (describing strict scrutiny as providing "extraordinary protection from the majoritarian political process"); David Schraub, Comment, The Price of Victory: Political Triumphs and Judicial Protection in the Gay Rights Movement, 77 U. CHI. L. REV. 1437, 1461 (2010) ("Additional judicial protection is extraordinary; rational basis review is ordinary."). The tension whereby a putatively race-minimizing standard like strict scrutiny cannibalizes its own antidiscrimination children can also be seen in Richard Primus's provocative argument that Title VII's disparate-impact provisions may violate contemporary equal protection doctrine as an impermissible racial classification. Richard A. Primus, Equal Protection and Disparate Impact: Round Three, 117 HARV. L. REV. 493 (2003).

80. U.S. CONST. amend. XIV,$\S 1$ ("No State shall . . . deny to any person within its jurisdiction the equal protection of the laws.").

81. FCC v. Beach Commc'ns, Inc., 508 U.S. 307, 313 (1993) (“'A] statutory classification that neither proceeds along suspect lines nor infringes fundamental constitutional rights must be upheld against equal protection challenge if there is any reasonably conceivable state of facts that could provide a rational basis for the classification."). 
intermediate $^{82}$ or strict scrutiny. ${ }^{83}$ Rational basis is the baseline, ${ }^{84}$ and the Court has been quite vague in articulating how a classification becomes "suspect." 85 Nonetheless, racial classifications are the paradigmatic-indeed, the original - example of the sort against which the Court applies strict scrutiny. ${ }^{86}$

\section{Accessing Strict Scrutiny}

The jurisprudential basis for providing heightened review to certain vulnerable classes has its genesis in the famous "footnote four" of Carolene Products. ${ }^{87}$ That case indicated that "discrete and insular minorities" may be particularly susceptible to majoritarian discrimination and, by the same token, be particularly unable to resort to the democratic process for redress. ${ }^{88}$ But since by definition minorities will

82. See Craig v. Boren, 429 U.S. 190, 197 (1976) (finding that sex classifications are subject to an intermediate level of scrutiny). This will be discussed further in Part III.A.2, infra.

83. City of Cleburne v. Cleburne Living Ctr., Inc., 473 U.S. 432, 440 (1985) (noting that strict scrutiny is applied "when a statute classifies by race, alienage, or national origin").

84. City of New Orleans v. Dukes, 427 U.S. 297, 303 (1976) (per curiam) ("Unless a classification trammels fundamental personal rights or is drawn upon inherently suspect distinctions such as race, religion, or alienage, our decisions presume the constitutionality of the statutory discriminations and require only that the classification challenged be rationally related to a legitimate state interest."); Jud Mathews \& Alec Stone Sweet, All Things in Proportion? American Rights Review and the Problem of Balancing, 60 EMORY L.J. 797, 811 (2011) ("[W] hat makes the scrutiny 'strict' is the fact that it negates the normal presumption that legislation will be treated as constitutionally valid unless the law fails basic rationality requirements." (emphasis in original)).

85. See, e.g., Lyng v. Castillo, 477 U.S. 635, 638 (1986) (considering whether the group members possess "obvious, immutable, or distinguishing characteristics that define them as a discrete group"); Mass. Bd. of Retirement v. Murgia, 427 U.S. 307, 313 (1976) (asking whether the group members have been "subjected to unique disabilities on the basis of stereotyped characteristics not truly indicative of their abilit[y]" to contribute meaningfully to society); San Antonio Indep. Sch. Dist. v. Rodriguez, 411 U.S. 1, 28 (1973) (listing the "traditional indicia of suspectness" as including whether the group was "saddled with such disabilities, or subjected to such a history of purposeful unequal treatment, or relegated to such a position of political powerlessness as to command extraordinary protection from the majoritarian political process"); see also Schraub, Unsuspecting, supra note 5, at 367-72

86. See Korematsu v. United States, 323 U.S. 214, 216 (1944) (“[A]11 legal restrictions which curtail the civil rights of a single racial group are immediately suspect. ... [C]ourts must subject them to the most rigid scrutiny."). Notably, "strict scrutiny" is no longer limited to racial classifications or, for that matter, equal-protection inquiries, having been exported to a wide variety of other constitutional inquiries (such as alleged impingements against "fundamental rights"). See generally Richard H. Fallon, Jr., Strict Judicial Scrutiny, 54 UCLA L. REV. 1267 (2007). Needless to say, post-racialism does not imply the end of strict scrutiny in those arenas.

87. United States v. Carolene Prods. Co., 304 U.S. 144, 152 n.4 (1938).

88. Id. Scholars have disagreed on the validity of this principle. Compare JOHN HART Ely, Democracy AND Distrust: A TheORY OF Judicial Review passim (1980) (drawing on Carolene Products to create a comprehensive "representation-reinforcing" theory of judicial review), with Bruce A. Ackerman, Beyond Carolene Products, 98 HARv. L. REv. 713, 723-24 (1985) (declaring Carolene Products "utterly wrongheaded in its diagnosis" and arguing that 
normally be losers in a democratic system ${ }^{89}$ something more must be required to render a classification dangerous enough to enjoy enhanced judicial scrutiny. Though the Court has not been exactly uniform in articulating its factors, ${ }^{90}$ San Antonio Independent School District $v$. Rodriguez is probably the most thorough listing of the "indicia of suspectness" that render a classification liable to face strict or heightened scrutiny. ${ }^{91}$ These include whether the group was "saddled with such disabilities, or subjected to such a history of purposeful unequal treatment, or relegated to such a position of political powerlessness as to command extraordinary protection from the majoritarian political process." 92 While the middle factor- "a history of purposeful unequal treatment"-remains active in perpetuity, the surrounding two diminish in salience as legally imposed disabilities disappear, and the political integration of racial minorities continues apace. ${ }^{93}$

In theory, then, strict scrutiny seems like it should be temporally limited-once the characteristics which caused the group to be seen as needing special fortification no longer hold, the protection would be lifted. ${ }^{94}$ In practice, no case has even contemplated (much less seriously threatened) the removal of a classification which previously received strict scrutiny from the ranks of "suspect classifications." ${ }^{\text {" }}$ Far from being a temporary shield responsive to particular social facts, strict scrutiny appears to be seen as a permanent designation..$^{96}$

Rodriguez should be the bulwark against this - for Rodriguez lays out a series of factors which would seem to provide the criteria for whether strict scrutiny should be maintained or abandoned. The problem, of course, is that Rodriguez has never been applied consistently even in how heightened scrutiny is extended and has been ignored entirely with respect to the question of lifting suspect status. ${ }^{97}$ Judges have exploited the indeterminacy latent in its three prongs to support wildly divergent results with respect to how a class receives heightened scrutiny. ${ }^{98}$ So it is that the Court declines to label gays and lesbians a suspect class because they are not "politically

"discrete and insular minorities" should be expected to fare better than average in a democratic system).

89. Holder v. Hall, 512 U.S. 874, 901 (1994) (Thomas, J., concurring in judgment) ("[I]n a majoritarian system, numerical minorities lose elections."); Ackerman, supra note 88, at 719 (declaring that a central part of any democratic system is that minorities lose elections).

90. See supra note 85.

91. 411 U.S. 1, 28 (1973).

92. Id.

93. Schraub, Unsuspecting, supra note 5, at 383 (identifying the suspect-status criteria as "transient in theory but concrete in fact").

94. Id. at 367; see also Felix Gilman, The Famous Footnote Four: A History of the Carolene Products Footnote, 46 S. TEX. L. REV. 163, 226 (2004) (“[O]nce a group is protected, it remains a protected class until the courts are willing to say that criteria for protection no longer exists [sic].").

95. Schraub, Unsuspecting, supra note 5, at 363.

96. Id. at 363 (describing suspect status as a "one-way ratchet").

97. See id.

98. See Sharon E. Rush, Whither Sexual Orientation Analysis?: The Proper Methodology When Due Process and Equal Protection Intersect, 16 WM. \& MARY BILL RTS. J. 685, 739 (2008) (observing, with respect to the differential treatment of sexual orientation, disability, and racial majorities, that "the cases increasingly tend to be all over the map"). 
powerless"99 while at the same time extending strict scrutiny to racial majorities (who - whatever other characteristics they might share-are most certainly not generally excluded from participation in the political process). ${ }^{100}$ The growing dissonance between the judiciary's general unwillingness to accord heightened scrutiny to anti-gay classifications and its continued application in racial contexts is reflective less of a cohesive legal principle than simple paralysis. ${ }^{101}$ Rodriguez, in other words, can block new groups from gaining access to strict scrutiny, but it has proven utterly inadequate as a guidepost for when such "extraordinary protection" should be removed.

Of course, for any given classification, one can justify the maintenance of strict scrutiny on the grounds that we have not yet progressed enough away from the conditions that necessitated judicial protection in the first place. ${ }^{102}$ With respect to race (one would argue), despite the advances of the past fifty years, it may be that racial minorities are still sufficiently disabled, still sufficiently isolated from the political mainstream, so as to deserve "extraordinary protection from the majoritarian political process." ${ }^{103}$ And indeed, this probably would be the defense of most strict-scrutiny advocates - that while a post-racial society is the goal, we have not yet achieved it.

99. Conaway v. Deane, 932 A.2d 571, 613 (Md. 2007) (rejecting heightened scrutiny with respect to a challenge against the ban on gay marriage); accord Lofton v. Sec'y of the Dep't of Children \& Family Servs., 358 F.3d 804, 818 \& n.16 (11th Cir. 2004) (citing primarily preLawrence cases in refusing to apply heightened scrutiny to Florida's law prohibiting gays from adopting); Andersen v. King Cty., 138 P.3d 963, 975 (Wash. 2006) (en banc) (plurality opinion) (same). Compare David Schraub, The Perils and Promise of the Holder Memo, 2012 CARDOZO L. REV. DE NOvo 187, 190-96 (noting the "peril" of high-profile advances by gayrights activists when trying to persuade courts to grant them heightened scrutiny), and Schraub, supra note 79, at 1456-60 (detailing how allegedly excessive gay political power has been used to stymie their efforts to gain heightened scrutiny), with Kenji Yoshino, Suspect Symbols: The Literary Argument for Heightened Scrutiny for Gays, 96 CoLUM. L. REV. 1753, 1806 (1996) ("Blacks are protected by three federal constitutional amendments, major federal Civil Rights Acts of 1866, 1870, 1871, 1875, .. 1957, 1960, 1964, 1965, and 1968, as well as by antidiscrimination laws in 48 of the states." (quoting High Tech Gays v. Def. Indus. Sec. Clearance Office, 909 F.2d 375, 378 (9th Cir. 1990) (Canby, J., dissenting from denial of rehearing en banc))).

100. Adarand Constructors, Inc. v. Pena, 515 U.S. 200, 227 (1995).

101. See, e.g., Evan Gerstmann, The Constitutional Underclass: Gays, Lesbians, and the Failure of Class-Based Equal Protection 24 (1999) ("The list of protected classes has been in stasis since [the mid-1970s]."); Suzanne B. Goldberg, Equality Without Tiers, 77 S. CAL. L. REV. 481, 485 (2004) (noting that the Court has not added a classification to the list of suspect classifications since the 1970s - closing the "set" almost immediately after first laying down the doctrinal criteria for suspect status in Rodriguez). The partial exception, of course, is adding racial majorities to the list in the late 1980s and early 1990s - but the Court conceptualized that as falling within its previous denotation of racial classifications as suspect. See Adarand, 515 U.S. at 227; City of Richmond v. J.A. Croson Co., 488 U.S. 469, 493 (1989) (plurality opinion).

102. Schraub, Unsuspecting, supra note 5, at 384 (articulating the "lack of opportunity" justification for maintaining strict scrutiny).

103. San Antonio Indep. Sch. Dist. v. Rodriguez, 411 U.S. 1, 28 (1973). Of course, phrasing the inquiry this way illustrates the strangeness of extending strict scrutiny to racial majorities, which never did and do not now experience these maladies. 
But that does not eliminate the tension with post-racialism so much as it illuminates it. Strict scrutiny makes sense only so far as we $d o$ believe that race plays a significant role in the distribution of American opportunity.

There is, in short, a fundamental hypocrisy in how proponents of post-racialism treat strict scrutiny. Consider how Abigail Thernstrom has characterized the Voting Rights Act: it should be viewed as "a curfew imposed in the wake of a riot-an emergency measure taken with the expectation that it would be lifted as soon as conditions allowed." 104 If this is right, surely it is equally right with respect to an "extraordinary" constitutional doctrine like strict scrutiny. There too, race-based legal doctrines should have an exit strategy. Once the conditions surrounding race in America no longer are such so as to command "extraordinary protection from the majoritarian political process"-in other words, when we actually are post-racial in the sense its proponents claim we already are ${ }^{105}$ - to continue to preserve strict scrutiny review would completely detach the doctrine from its jurisprudential moorings: a supposedly exceptional safeguard necessary only in the context of extraordinary, democracy-defeating prejudice and discrimination.

\section{Applying Strict Scrutiny}

Once it is found that a classification is subject to strict scrutiny, the black-letter test requires that the challenged statute be comprised of "narrowly tailored measures that further compelling governmental interests." 106 Though strict scrutiny is often described as "fatal in fact," 107 it is reasonably well established that the doctrine permits the use of race in a few narrow circumstances. ${ }^{108}$ One rather controversial and precarious carve-out for the use of race is for promoting diversity in educational settings. ${ }^{109}$ But even the staunchest critics of governmental racial classifications

104. Abigail M. Thernstrom, Whose Votes Count?: Affirmative Action and MinORITY Voting Rights 46 (1987).

105. Giradeau Spann identifies the following three post-racial assumptions:

First, current racial minorities are no longer the victims of significant discrimination. Second, as a result, race-conscious efforts to benefit racial minorities at the expense of whites constitute a form of reverse discrimination against whites that must be prevented in the name of racial equality. Third, because the postracial playing field is now level, any disadvantages that racial minorities continue to suffer must be caused by their own shortcomings rather than by the lingering effects of now-dissipated past discrimination.

Girardeau A. Spann, Disparate Impact, 98 GEO. L.J. 1133, 1135 (2010).

106. Adarand Constructors, Inc. v. Pena, 515 U.S. 200, 227 (1995).

107. Gerald Gunther, The Supreme Court, 1971 Term-Foreword: In Search of Evolving Doctrine on a Changing Court: A Model for a Newer Equal Protection, 86 HARv. L. REv. 1, 8 (1972).

108. Adarand, 515 U.S. at 237 (arguing against "the notion that strict scrutiny is 'strict in theory, but fatal in fact"” (quoting Fullilove v. Klutznick, 448 U.S. 448, 518-19 (1980) (Marshall, J., concurring in judgment))); see Adam Winkler, Fatal in Theory and Strict in Fact: An Empirical Analysis of Strict Scrutiny in the Federal Courts, 59 VAND. L. REv. 793, 834 (2006) (finding that between 1990 and 2003, federal courts upheld racial classifications analyzed under strict scrutiny in twenty-seven percent of all cases).

109. Fisher v. Univ. of Tex. at Austin, 136 S. Ct. 2198, 2210 (2016) ("[A] university may 
agree it can be used to directly rectify prior governmental discrimination. ${ }^{110}$ In general, the less willing a Justice is to believe that we have achieved our post-racial ambitions, the more willing he or she is to countenance the use of race to intervene against the remaining inequities. ${ }^{111}$

Strict scrutiny is thus often characterized as a way of diminishing the use of race in the public sphere, in that race is a forbidden ground for government action absent a few exceptionally compelling circumstances. When government elects to use race - even in seemingly innocuous and evenhanded ways - it can act to elevate race's significance even beyond whatever baseline exists in normal politics. ${ }^{12}$ So in Anderson v. Martin, the Supreme Court struck down a Louisiana statute which printed the race of public office candidates on the ballot. ${ }^{113}$ On its face, this law seems to be the epitome of a "benign" use of race: treating all races identically and subjecting none to any official impairment or restriction of any kind. ${ }^{114}$ Of course, it is almost certain that the Louisiana legislature had decidedly impure motives in passing this law, and the Court was not blind to this reality. ${ }^{115}$ But even if Louisiana had

institute a race-conscious admissions program as a means of obtaining 'the educational benefits that flow from student body diversity." (quoting Fisher v. Univ. of Tex. at Austin, $133 \mathrm{~S}$. Ct. 2411, 2419 (2013))); Grutter v. Bollinger, 539 U.S. 306, 343 (2003) (affirming the legitimacy of the diversity rationale); Regents of the Univ. of Cal. v. Bakke, 438 U.S. 265, 311-15 (1978) (opinion of Powell, J.) (holding that promoting racial diversity constituted a compelling governmental interest so long as it was not the only factor considered by a public university's admissions program).

110. Parents Involved in Cmty. Sch. v. Seattle Sch. Dist. No. 1, 551 U.S. 701, 751 (2007) (Thomas, J., concurring) ("The Constitution generally prohibits government race-based decisionmaking, but this Court has authorized the use of race-based measures for remedial purposes in two narrowly defined circumstances. First, in schools that were formerly segregated by law, race-based measures are sometimes constitutionally compelled to remedy prior school segregation. Second, in Croson, the Court appeared willing to authorize a government unit to remedy past discrimination for which it was responsible." (citing Richmond v. J.A. Croson Co., 488 U.S. 469, 504 (1989))).

111. Helen Norton, The Supreme Court's Post-Racial Turn Towards a Zero-Sum Understanding of Equality, 52 WM. \& MARY L. ReV. 197, 202-03 (2010).

112. The Court has, with some embarrassment, conceded that race is at least descriptively relevant to the voting decisions of many Americans and that voters have the right to make such judgments. Anderson v. Martin, 375 U.S. 399, 402 (1964) (affirming "the right of a citizen to cast his vote for whomever he chooses and for whatever reason he pleases"); see also Wright v. Rockefeller, 376 U.S. 52, 66 (1964) (Douglas, J., dissenting) (“Of course race, like religion, plays an important role in the choices which individual voters make from among various candidates."); John Hart Ely, Commentary, Standing To Challenge Pro-Minority Gerrymanders, 111 HARV. L. REV. 576, 590 (1997) ("[I]t is the right of a citizen to choose among constitutionally qualified candidates on any basis she wants - good looks, height, religion, gender, race, a resemblance to Uncle Lester-and although some of them are lamentable, all are constitutionally sheltered bases for choosing which lever to pull." (footnote omitted)).

113. 375 U.S. at 403-04.

114. Van Alstyne, supra note 1, at 788-89; cf. Loving v. Virginia, 388 U.S. 1, 8-11 (1967) (analyzing the claim that Virginia's bar on interracial marriage does not violate the Equal Protection Clause because the restriction falls upon both races equally).

115. Anderson, 375 U.S. at 404 ("Obviously, Louisiana may not bar Negro citizens from offering themselves as candidates for public office, nor can it encourage its citizens to vote for 
completely innocent intentions, the Court observed that the effect of this specific use of race was particularly likely to enhance the salience of race even beyond that already expected to exist in electoral politics. "[B]y placing a racial label on a candidate at the most crucial stage in the electoral process - the instant before the vote is cast - the State furnishes a vehicle by which racial prejudice may be so aroused as to operate against one group because of race and for another." 116

But the claim that strict scrutiny in every case acts to minimize the salience of race in American institutions is hardly a self-evident proposition. Note that the argument in Anderson is specific to the particular statute before the Court, and what Anderson did that many subsequent cases did not was actually make a defined argument for why - given the motives and effects of the statute - the particular government usage of race was likely to increase race's relevance in a morally precarious manner. ${ }^{117}$ It does not follow that in every instance where a governmental body utilizes racial classifications, it will make race more salient. Indeed, in other situations, the courts have permitted - and federal antidiscrimination law sometimes requires - the collection and publication of racial data, without running through traditional strict-scrutiny analysis. ${ }^{118}$

While sometimes legal suppression of race does act to reduce its impact on public affairs, strict scrutiny often elevates rather than diminishes the salience of race. David Strauss gives the example of a legislature that, upon finding that race genuinely had a significant statistical correlation with driving behavior, used race as a proxy for the minimum age one could receive a driver's license. ${ }^{119}$ Assuming the legislature genuinely wanted nothing more than to use the most efficient, lowest-cost proxy for drivers' safety (and race turned out to be that proxy), the decision to overturn that statute (as modern strict scrutiny doctrine inevitably would) is in an important sense more race conscious than the legislature's enactment itself. "The legislature's decision is

a candidate solely on account of race. And that which cannot be done by express statutory prohibition cannot be done by indirection." (citation omitted)).

116. Id. at 402 .

117. Cf. Deborah Hellman, Two Types of Discrimination: The Familiar and the Forgotten, 86 CALIF. L. REv. 315, 340-41 (1998) (arguing that Anderson gestured in the direction of articulating a theory for why and in what circumstances non-proxy racial discrimination is impermissible but that this thread was dropped in future cases which began to identify all such classifications as inherently unconstitutional); Neil S. Siegel, Race-Conscious Student Assignment Plans: Balkanization, Integration, and Individualized Consideration, 56 DuKE L.J. 781, 805-08 (2006) (positing a continuum of judicial treatment of race, based on the Justices' assessment of the risk that the use of race will increase or diminish racial balkanization).

118. See, e.g., Caulfield v. Bd. of Educ., 583 F.2d 605, 611-12 (2d Cir. 1978) (upholding the collection of racial data in the course of an investigation by the Office of Civil Rights in New York); United States v. New Hampshire, 539 F.2d 277, 279 (1st Cir. 1976) (upholding the Civil Rights Act's requirement that racial data be collected for purpose of civil rights enforcement); Hamm v. Va. State Bd. of Elections, 230 F. Supp. 156, 158 (E.D. Va. 1964) (upholding a Virginia statute requiring that the race of the parties be designated on divorce decrees), aff'd sub nom. Tancil v. Woolls, 379 U.S. 19 (1964); see also Jack M. Balkin \& Reva B. Siegel, Essay, Principles, Practices, and Social Movements, 154 U. PA. L. REV. 927, 937-39 (2006) (detailing the shift in attitudes regarding the permissibility of government collecting racial data).

119. Strauss, supra note 22 , at 108-11. 
colorblind in the sense that it treats race exactly like any other characteristic. The court's decision is race-conscious because it singles out race as a special characteristic and forces people to become conscious of race in a way they would not otherwise be." 120

Despite this complexity, it is undeniable that the Court's framing of when the use of race is permissible is suffused with a desire to minimize race's salience - an effort to make America post-racial. Take the well-accepted ability to use race as a remedy for past racial discrimination. ${ }^{121}$ Given America's sustained history of racist discrimination, this opening could loom quite large. Cognizant of this possibility, the Supreme Court in Wygant v. Jackson Board of Education was explicit in precluding the use of racial classifications solely to remedy "societal discrimination." 122 The problem with relying on "societal discrimination" as a hook for race-conscious remediation is that it could theoretically allow for the endless use of race- - "remedies that are ageless in their reach into the past, and timeless in their ability to affect the future." 123 This, of course, would run precisely counter to post-racial ambitions, which anticipate an America where race has faded from prominence. ${ }^{124}$

Wygant's mantra has echoed constantly in subsequent cases. ${ }^{125}$ The Court has consistently cast its jurisprudence against a world where "race will always be relevant in American life." 126 Where the Court does allow race to be considered, it

120. Id. at 111.

121. See Parents Involved in Cmty. Sch. v. Seattle Sch. Dist. No. 1, 551 U.S. 701, 752-53 (2007) (Thomas, J., concurring) (acknowledging that, where the state has maintained a policy of de jure discrimination, "race-based remedial measures are sometimes required").

122. 476 U.S. 267, 274 (1986) (plurality opinion) ("This Court never has held that societal discrimination alone is sufficient to justify a racial classification. Rather, the Court has insisted upon some showing of prior discrimination by the governmental unit involved before allowing limited use of racial classifications in order to remedy such discrimination."); see also Parents Involved, 551 U.S. at 754 (Thomas, J. concurring) (citing Wygant to observe that "[a]side from constitutionally compelled remediation in schools, this Court has permitted government units to remedy prior racial discrimination only in narrow circumstances").

123. Wygant, 476 U.S. at 276 (concluding that "[s]ocietal discrimination, without more, is too amorphous a basis for imposing a racially classified remedy"); see also Parents Involved, 551 U.S. at 731 (plurality opinion) ("[I]n Seattle the [race-conscious school integration] plans are defended as necessary to address the consequences of racially identifiable housing patterns. The sweep of the mandate claimed by the district is contrary to our rulings that remedying past societal discrimination does not justify race-conscious government action.”).

124. See also Ward, supra note 46, at 603-04 (worrying about making racial or ethnic divisions into a "permanent" part of our governmental and political system).

125. See, e.g., Parents Involved, 551 U.S. at 730-31 (plurality opinion) (attacking Seattle and Louisville's "racial balancing" plans as sanctioning the indefinite and possibly perpetual use of race); Metro Broad. Inc., v. FCC, 497 U.S. 547, 614 (1990) (O’Connor, J., dissenting) (worrying that "proportional representation of various races" would "support indefinite use of racial classifications . ..”); City of Richmond v. J.A. Croson Co., 488 U.S. 469, 498 (1989) (concerned about usages of race that have "no logical stopping point" (quoting Wygant, 476 U.S. at 275 (plurality opinion))).

126. Croson, 488 U.S. at 495 (plurality opinion) (worrying that allowing "benign" racial classifications will mean that "race will always be relevant in American life, and that the 'ultimate goal' of 'eliminat[ing] entirely from governmental decisionmaking such irrelevant 
demands strict temporal limits. So, in Grutter v. Bollinger, ${ }^{127}$ the Supreme Court endorsed diversity as a compelling state interest sufficient to sanction racial affirmative action but declared its expectation that " 25 years from now, the use of racial preferences will no longer be necessary to further the interest approved today." ${ }^{128}$ Having given a narrow carve-out for the use of race, the Court proceeded to place it on the clock. ${ }^{129}$ Like in Wygant, the goal was to forestall a situation where racially inflected decision making was a permanent feature of American governance. For the Court to admit that might be necessary ${ }^{130}$ would place it in fundamental conflict with the widely popular post-racial ambition. ${ }^{131}$

Yet, the "shot clock" logic of Wygant and Grutter raises a serious problem for proponents of permanently elevating race to strict-scrutiny status. At the time strictscrutiny doctrine was first being developed and applied, there is no question it fit well within the contours of specific remediation of governmentally sponsored discrimination. Korematsu ${ }^{132}$ - the original strict-scrutiny case - came nearly twenty years before the passage of the Civil Rights Act of 1964, ${ }^{133}$ and America still permitted de jure segregation of public facilities. ${ }^{134}$ As this sort of official governmental racism grows more distant, however, it becomes harder to hinge continued use of strict scrutiny on its supposedly remedial qualities. Instead, the continued enforcement of strict scrutiny appears motivated more by general reference to the historical pedigree of race in America. Proposals to even retreat to intermediate scrutiny in evaluating certain racial classifications are said to "turn[] back the clock" to a darker period in America's racial jurisprudence ${ }^{135}$ without recognizing the incongruity: simultaneously asserting that racism is so pervasive as to be permanently akin to the

factors as a human being's race' will never be achieved" (alteration in original) (citation omitted) (quoting Wygant, 476 U.S. at 320 (Stevens, J., dissenting))).

127. 539 U.S. 306 (2003).

128. Id. at 343 .

129. Id. at 342 ("[R]ace-conscious admissions policies must be limited in time. . . [A]11 governmental use of race must have a logical end point.").

130. At the very least, there are some indications that twenty-five years may have been an unduly optimistic assessment. Alan Krueger, Jesse Rothstein \& Sarah Turner, Race, Income, and College in 25 Years: Evaluating Justice O'Connor's Conjecture, 8 AM. L. \& ECON. REv. 282 (2006) (predicting that, even assuming bias is no longer a factor, the legacy of past racial discrimination will continue to elicit noticeable racially disparate effects in twenty-five years).

131. See Vijay S. Sekhon, Maintaining the Legitimacy of the High Court: Understanding the "25 Years" in Grutter v. Bollinger, 3 ConN. PuB. INT. L.J. 301, 308-10 (2004) (arguing that the twenty-five-year limit was an effort by the Court to preserve its legitimacy with the American public).

132. Korematsu v. United States, 323 U.S. 214 (1944).

133. Pub. L. No. 88-352, 78 Stat. 241.

134. The first crack in segregationist armor had emerged, Missouri ex rel. Gaines v. Canada, 305 U.S. 337, 349-50 (1938) (striking down Missouri's policy of paying for the outof-state education of Black students in lieu of integrating the state's law school), but Plessy $v$. Ferguson, 163 U.S. 537 (1896), and with it, the broader principle of "separate but equal," remained good law.

135. Metro Broad. Inc., v. FCC, 497 U.S. 547, 633 (1990) (Kennedy, J., dissenting). 
situation which prevailed in pre-Civil Rights America and yet so sporadic as to foreclose race-conscious remedies in all but the narrowest range of cases. ${ }^{136}$

\section{B. Putting Race Before Our Eyes}

The previous section identified two doctrinal points of tension between the ideal of post-racialism and the way in which race is elevated via strict scrutiny. First, the basic premises by which race is accorded suspect status-its supposed particular vulnerability to majoritarian oppression and democratic failure-are by necessity less and less credible the more stridently we proclaim ourselves "post-racial." Second, while the use of race is supposed to be authorized only as a temporary remedy for discrete and ongoing racial ailments, the continued application of strict scrutiny seems to stem less from such particularized wrongs and more from a generalized invocation of our racist past.

One cogent critique of the above is that it is simply too-cute formalism. Sure, technically the Court has not harmonized its strict-scrutiny doctrine with its general strictures on the use of race. But all this means is that the Court has sub rosa carved out an exemption for the application of its scrutiny doctrine. ${ }^{137} \mathrm{I}$ do not believe this objection is entirely on target: it does not seem to give due credence either to the Court's very specific limitations on what makes a particular classification subject to strict scrutiny, ${ }^{138}$ nor does it answer Wygant's fears of a race-based doctrine extending endlessly into the future. ${ }^{139}$ Nonetheless, in this subpart, I will extend beyond doctrinal analysis to argue why strict scrutiny and post-racialism exist in inherent tension.

As noted previously, one concept of post-racialism is predicated upon making race "disappear," 140 and strict scrutiny is a very blunt and direct governmental effort to suppress race. The presumption is that the usage of race in governmental decision making causes us to let slip decades of hard-won progress towards diminishing the relevance of race, and so "race becomes important once more." ${ }^{141}$ But by creating an effective taboo around the usage or discussion of race, strict scrutiny effectively elevates, rather than suppresses, the public salience of race. As Michel Foucault argued with respect to sexuality, the proscription around speaking of sex led to an "explosion" of discourses surrounding it. ${ }^{142}$ To insistently not speak of something is

136. See Schraub, Unsuspecting, supra note 5, at 413 (describing the problem of "partial racial politics").

137. In Grutter, the Court declared that "racial classifications, however compelling their goals, are potentially so dangerous that they may be employed no more broadly than the interest demands." Grutter v. Bollinger, 539 U.S. 306, 342 (2003). It may be, for example, that the Court believes that permanent maintenance of race-based strict scrutiny is the narrowest possible mechanism for ensuring that race is otherwise excised from American society.

138. See supra Part II.A.1.

139. See supra Part II.A.2.

140. See supra Part I.A.

141. Van Alstyne, supra note 1, at 778 n.10.

142. 1 Michel Foucault, The History of SeXuality 17-18 (Robert Hurley trans., Vintage Books 1990) (1978); see also Neil Gotanda, A Critique of "Our Constitution Is Color- 
indistinguishable from speaking about it constantly. ${ }^{143}$ And so it is with race: that we have a systemic and unyielding structure of rules and regulations geared at prohibiting the usage of race in any form or context necessarily heightens the salience of race in the mind of the public. ${ }^{144}$ Consequently, "racelessness implies not the end of racial consciousness but its ultimate elevation to the given." 145 The power of race is at its apex when it need not be spoken of to be omnipresent.

As Catharine MacKinnon observes, there are a whole host of potential identity characteristics upon which we might think systematically differential outcomes would be unjust, but our antidiscrimination law covers only a scarce, special few. ${ }^{146}$ The entire structure of antidiscrimination law is premised on the exceptional quality of the identity axes it targets - it represents "an exception to the legal system's basic unwillingness to intervene in those processes of social selection." ${ }^{147}$ Precisely because this treatment is so extraordinary, it is extremely unlikely that a doctrine which seeks to bury race could ever succeed in expunging race from our collective consciousness; if anything, it enhances its presence.

Research into the psychology of prejudice is beginning to bear this intuition out. "Suppressing" race in the manner encouraged by strict scrutiny is facially consistent with the broadly accepted contemporary consensus on race, namely, that racism is wrong and that we should strive to treat all persons fairly regardless of their racial heritage. Again, this is a phenomenon of long-standing import-Gunnar Myrdal's description of the "American dilemma" was precisely one of attempting to sublimate racist attitudes as inconsistent with a broader American ethos of liberal equality. ${ }^{148}$

Blind,” 44 StAn. L. Rev. 1, 23 (1991) (“A subject is defined by its negation, hence, an assertion of nonconsideration necessarily implies consideration. The stronger and more defined the character of racial recognition, the clearer and more sharply drawn its dialectical opposite, racial nonrecognition." (italics in original)).

143. Cf. Slavoj Žižek, Welcome to the Desert of the Real!: Five Essays on SEPTEMBER 11 AND RELATED DATES 56 (2002) ("Evil resides (also) in the innocent gaze itself which perceives Evil all around.").

144. Strauss, supra note 22, at 112 ("The fact is that the prohibition against racial discrimination makes people intensely race-conscious. That is because when race is involved, people must refrain from acting in the way they would act toward any comparable characteristic."). Richard Epstein is one of the few willing to take this insight for all it's worth — advocating the repeal of Title VII on the grounds that the free market should drive out invidious racial discrimination and affirming that any residual disparities would be the result of efficient ordering by rational economic actors. RichARD A. EPSTEIN, ForbidDEN GROUNDS: THE CASE AGAINST EMPLOYMENT DISCRIMINATION LAWS 46 (1992).

145. David Theo Goldberg, The Racial State 236 (2002).

146. Catharine A. MacKinnon, Sexual Harassment of Working Women 106 (1979) (observing that there is a "vast range of arguably unjust but shared bases for human differentiation which Congress and the courts do not see as their function to police").

147. Id.

148. 1 Gunnar Myrdal, An AmericAn Dilemma lxxix (Transaction 1996) (1944) ("The 'American Dilemma' . . . is the ever-raging conflict between, on the one hand, the valuations preserved on the general plane which we call the 'American Creed,' where the American thinks, talks, and acts under the influence of high national and Christian precepts, and, on the other hand, the valuations on specific planes of individual and group living, where personal 
Insofar as conscious suppression of racial biases is both externally valid (in that, ideologically speaking, to say that one did not intentionally utilize racial considerations is sufficient to satisfy one's public obligations with respect to race) and internally valid (in that consciously avoiding race allows one to convince oneself that one's behavior is consistent with one's egalitarian moral principles with respect to race) as a way of "handling" race, this strategy represents a highly attractive mechanism for resolving Myrdal's dilemma. ${ }^{149}$

But the effort to simply fiat away racist attitudes via conscious declaration does little to affect racial attitudes or presuppositions that lie beyond conscious control. Instead, it merely encourages people to suppress elements of their psyche which clash with an idealized self-image of themselves as nonracist. ${ }^{150}$ The act of suppression, in other words, creates a conflict between conscious political commitments (here, that race is irrelevant) and subconscious attitudes (where race remains quite relevant) - and that conflict itself creates a tension that may manifest in renewed racial hostility. ${ }^{151}$ Social psychologists have documented a "rebound effect" where

and local interests; economic, social, and sexual jealousies; consideration of community prestige and conformity; group prejudice against particular persons or types of people; and all sorts of miscellaneous wants, impulses, and habits dominate his outlook.")

149. See Samuel R. Bagenstos, The Structural Turn and the Limits of Antidiscrimination Law, 94 CALIF. L. REV. 1, 9 (2006) ("[A person] can believe quite sincerely that she is making a 'neutral' decision 'on the merits.' And . . . the [person's] belief that she acted on the merits will be reinforced by the desire to believe that she treats minorities in an equitable fashion." (footnote omitted)); Hanson \& Hanson, supra note 76, at 419 ("[P] eople crave justice ... . $[\mathrm{H}]$ owever, ... we often satisfy the craving through troubling means: when alleviating innocent suffering is at all difficult or complex, people reconceive the victim as deserving the suffering by assigning negative characteristics to her."). See generally E. Ashby Plant \& Patricia G. Devine, Internal and External Motivation To Respond Without Prejudice, $75 \mathrm{~J}$. PERSONALITY \& SOC. PSYCHOL. 811 (1998) (distinguishing between social versus intrinsic motivations encouraging people to refrain from exhibiting prejudiced responses).

150. John F. Dovidio \& Samuel L. Gaertner, Aversive Racism and Selection Decisions: 1989 and 1999, 11 PSYCHOL. SCI. 315, 315 (2000) ("The aversive-racism framework further suggests that contemporary racial bias is expressed in indirect ways that do not threaten the aversive racist's nonprejudiced self-image. Because aversive racists consciously recognize and endorse egalitarian values, they will not discriminate in situations in which they recognize that discrimination would be obvious to others and themselves - for example, when the appropriate response is clearly dictated. However, because aversive racists do possess negative feelings, often unconsciously, discrimination occurs when bias is not obvious or can be rationalized on the basis of some factor other than race."); Charles R. Lawrence III, The Id, the Ego, and Equal Protection: Reckoning with Unconscious Racism, 39 STAN. L. REV. 317, 322-23 (1987) ("[T] he human mind defends itself against the discomfort of guilt by denying or refusing to recognize those ideas, wishes, and beliefs that conflict with what the individual has learned is good or right."); see also Alan Helmreich \& Paul Marcus, Introduction: BlackJewish Conflict, in Blacks and Jews on the Couch: Psychoanalytic Reflections on Black-Jewish Conflict 1, 6 (Alan Helmreich \& Paul Marcus eds., 1998) (arguing that in order "to reduce racist and bigoted attitudes and behavior, it is precisely those unacceptable feelings, attitudes, and attributes that students are ashamed of and have disavowed, repressed, and projected that need to be 'worked through"' (quoting Mark Bracher, Editor's Introduction, 1 J. FOR PSYChOANALYSIS Culture \& Soc. 1, 10 (1996))).

151. Samuel L. Gaertner \& John F. Dovidio, The Aversive Form of Racism, in PreJudice, 
persons attempting to police their behavior so as to minimize prejudicial responses "chok[e] under pressure" and instead demonstrate colder behavior towards outgroups. ${ }^{152}$ While suppression can be effective for short time periods, "the ironic outcome [is] that the stereotype becomes hyperaccessible when the suppression instruction is relaxed or when cognitive resources are drained." 153 Persons are simply unable to maintain a state of constant, uninterrupted vigilance regarding their use of race. Eventually, the levies break and racial thinking comes flooding back-to the shame of the thinker, who begins to associate interracial interaction with anxiety and apprehension. A social model which simultaneously reinforces race's pervasiveness while condemning those who notice race is a social model guaranteed to fail—particularly if the goal is to become "post-racial."

One does not have to delve into our psychological depths to understand the tension with post-racialism, however. The demand for strict review of racial classifications reflects the belief that "[ $t]$ he state may neither use race in its own business nor may it encourage others to take it into account." ${ }^{154}$ But by barring racial discrimination and classifications, we've already expressed that race is something especially worthy of our concern and attention. As David Strauss puts it, "race is already before our eyes." 155 "The prohibition against [racial] discrimination forces us to recognize that race is different from other bases for classifying people and forces us to act differently toward race from the way we act toward other characteristics." 156

Unlike most other identity axes, we have singled out race as something uniquely and systematically dangerous. Having made that determination, however, it is unclear how Wygant's admonition against using the generic history of "societal discrimination" to justify race-conscious remedies garners any sort of normative punch. ${ }^{157}$ In effect, we are making the declaration that — far from being post-racial - race and racism are so pervasive in our society that it demands a separate,

DisCRIMINATION, AND RACISM 61, 64 (John F. Dovidio \& Samuel L. Gaertner eds., 1986) (finding that the tension between conscious commitments and unconscious attitudes creates "anxiety or uneasiness" surrounding interracial interactions, which is then transmuted onto the minority group in the form of renewed prejudice). A similar effect might occur in the realm of sexual orientation, where researchers have found a class of persons with suppressed homosexual attractions that demonstrate heightened public hostility to gays and lesbians. Netta Weinstein, William S. Ryan, Cody R. DeHaan, Andrew K. Przybylski, Nicole Legate \& Richard M. Ryan, Parental Autonomy Support and Discrepancies Between Implicit and Explicit Sexual Identities: Dynamics of Self-Acceptance and Defense, 102 J. PERSONALITY \& SOC. PSYCHOL. 815 (2012).

152. Jacquie D. Vorauer \& Cory A. Turpie, Disruptive Effects of Vigilance on Dominant Group Members' Treatment of Outgroup Members: Choking Versus Shining Under Pressure, 87 J. Personality \& Soc. Psychol. 384, 385, 395 (2004); accord, e.g., Margo J. Monteith, Jeffrey W. Sherman \& Patricia G. Devine, Suppression as a Stereotype Control Strategy, 2 Personality \& Soc. Psychol. Rev. 63, 78 (1998).

153. Monteith et al., supra note 152, at 77.

154. Van Alstyne, supra note 1, at 790.

155. Strauss, supra note 22, at 131.

156. Id.

157. See supra note 122 and accompanying text. 
freestanding legal structure dedicated to eradicating it and it alone. ${ }^{158}$ If "societal discrimination" of this sort is sufficient to admit one race-conscious legal doctrine (strict scrutiny), it isn't clear why it can't admit others.

A post-racial society is not one which is forced to treat race as its ultimate "monster in the closet," against which no quarter can be given and no compromise extended. That may be a practical response to race in a society suffused with racism or even a permanent policy for one pessimistic about the process of ever transcending a history of racism. ${ }^{159}$ But the one thing it isn't is "post-racial," or a strategy for getting us there. ${ }^{160}$

\section{STRICT SCRUTINY IN A POST-RACIAL AMERICA}

The prior Parts have sought to demonstrate a deep and intractable conflict between becoming "post-racial" and using strict scrutiny. Conceptually, race cannot be transcended while remaining our "monster in the closet." Doctrinally, the application of strict scrutiny to racial categorization violates several well-established precepts over when race can and cannot be used: it is timeless where we claim to desire finitude, ${ }^{161}$ justified by a general social history of discrimination rather than any specific, identifiable ailment, ${ }^{162}$ and provided by reference to a class with increasing political influence when it is supposed to be restricted only to those who are uniquely politically dispossessed. ${ }^{163}$

Does this mean strict scrutiny is worthless? I do not believe so. Rather, what is needed is a more nuanced inquiry: in which contexts does strict scrutiny help advance rather than hold back the cause of racial justice? Moreover, the conflict identified above can do more - it can clarify and sharpen precisely what it is we mean by our "post-racial" aspiration. In this Part, I explore three different manners by which the above tension between post-racialism and strict scrutiny can be resolved. First, I examine how our contemporary racial jurisprudence would change if we abandoned strict scrutiny altogether-in effect, if we acted as if we truly were a post-racial society already. ${ }^{164}$ Then I turn to the opposite extreme — defending strict scrutiny to the extent that we believe America will never be post-racial and where race always is so dangerous that it must be suppressed at all costs. ${ }^{165}$ Finally, I revisit the second model of post-racialism, taking religion and indigenous status as a model. ${ }^{166} \mathrm{In}$ both cases, there have been long histories of severe social conflict that we are trying to transcend.

158. Cf. Richard Delgado, Rodrigo's Twelfth Chronicle: The Problem of the Shanty, 85 GEO. L.J. 667, 677 (1997) (arguing that "[r]acism is woven into the warp and the woof of society").

159. See infra Part III.B.

160. Strauss, supra note 22, at 112-13 ('If we are trying to escape 'racial thinking,' if we are trying to achieve a society in which people really are as unaware of each others' race as they are of eye color, the prohibition against discrimination is not the way to do it.").

161. See supra notes 123-31 and accompanying text.

162. See supra notes 122-23, 133-34 and accompanying text.

163. See supra notes 87-99 and accompanying text.

164. See infra Part III.A.

165. See infra Part III.B.

166. See infra Part III.C. 
But in both cases, the manner by which we are attempting to get "post" is not by suppressing the identity axis but rather by turning it into something no longer feared.

\section{A. The End of Strict Scrutiny}

As I have argued, strict scrutiny is precisely the sort of extraordinary usage of race that should be rendered superfluous in a truly post-racial society. To put the issue bluntly: if we are truly post-racial (at least under the first conception of post-racial), we should have no hesitation in jettisoning strict scrutiny, because we should expect the result to be-absolutely nothing. If post-racialism means race is, descriptively speaking, utterly irrelevant in modern life, a world without strict scrutiny should look precisely identical to one with it (except that it omits the now-anachronistic doctrinal superordination of race). A post-racial society would have no reason for any interest group to even contemplate proposing a racial classification. And if an idiosyncratic locality or institution did decide to create one, it would not raise any alarm bells. It might seem strange or peculiar, akin to a distinction based on eye color, or it might seem like a random but innocuous method of social organization, like a distinction based on the alphabetical order of names, but it would not signal anything dangerous. ${ }^{167}$

Of course, very few of us are willing to put our money where our mouths are in this respect. That alone is powerful evidence that we don't actually believe what claims exist of having already successfully become post-racial. And the arguments above have cast serious doubt as to whether strict scrutiny can complete a transition to a post-racial America. This section will explore what America's race jurisprudence and legal structure might look like were we truly committed to the sort of "postracialism" that would render race akin to eye color, or other "irrelevant" characteristics.

\section{Race Like Anything Else-Peremptory Strikes and the Strange Career of Hereditary Preferences}

It is difficult to talk about how "race" might be used in a "post-racial" society. If race were irrelevant, why would anybody use it at all? Peremptory strikes are a good proxy for how race might be treated in a "post-racial" legal regime because they represent a scenario where law explicitly warrants decision making based on criteria

167. As Mario Barnes, Erwin Chemerinsky, and Trina Jones recently observed, this was more or less the argument made by the Court in Plessy, which used rhetoric similar to modern "post-racial" themes in minimizing the social salience of race in America. Barnes et al., supra note 58, at 969 \& n.10; see Plessy v. Ferguson, 163 U.S. 537, 551 (1896) (arguing that any imputation of Black inferiority stemming from railcar segregation exists "solely because the colored race chooses to put that construction upon it"); see also Ronald Turner, Plessy 2.0, 13 LeWIS \& Clark L. Rev. 861, 917 (2009) (arguing that Plessy and Parents Involved are united in their deliberate blindness to the continued public salience of race in America). In Plessy, of course, this appeal to the purportedly innocent character of racial segregation was willfully blind to the continued salience of race, which rendered these distinctions the furthest thing from innocuous. If society truly were post-racial, however, it would be a different matter entirely. 
normally thought of as irrelevant. The whole reason one uses a peremptory strike to eliminate a juror is that one does not possess a "good" reason - that is, one sufficient to establish for-cause removal- to do so. And indeed, the debate over race-based peremptory strikes in juror selection is one area where a "second model" post-racial position has emerged, ${ }^{168}$ albeit primarily in dissent.

In Batson v. Kentucky, ${ }^{169}$ the Supreme Court held for the first time that peremptory challenges of potential jurors could not be made on the grounds of race. ${ }^{170}$ Where a party is alleged to have made a race-based juror strike, she must proffer "a neutral explanation" for the challenge. ${ }^{171}$ This represents a rather drastic departure from the entire point of a peremptory challenge, which normally permits a juror to be struck "for any reason at all, as long as that reason is related to [the prosecutor's] view concerning the outcome." 172

Here again, ${ }^{173}$ the majority places race in an extraordinary legal position. Most group affiliations - even when the group is defined by its utilization of a constitutional right—do not enjoy Batson's protection. ${ }^{174}$ Lawyers are not barred from striking jurors based on group characteristics, ${ }^{175}$ even "crudely stereotypical" assessments of group characteristics. ${ }^{176}$ In other words, race is not being carved out from the broader thrust of peremptory challenges because it represents an illogical reason for striking a juror. Peremptory challenges are not an area where the law even purports to normally require legal actors to have "good" reasons for their decisions. Race is carved out because we believe race is extraordinarily and especially dangerous, necessitating unique rules restricting its deployment even in an area where we are by design exceptionally lax in requiring legal actors to conform their behavior to normal standards of rationality or propriety.

Critics of the Batson regime have observed that this extraordinary treatment of race disadvantages litigants who believe - perhaps with good reason, perhaps not - that the racial composition of their jury matters quite a bit to the outcome of their

168. See supra Part I.B.

169. 476 U.S. 79 (1986).

170. Id. at 89 . Though Batson dealt solely with the actions of prosecutors in criminal actions, Batson has since been extended to any party in civil and criminal cases. Georgia v. McCollum, 505 U.S. 42, 59 (1992) (Batson applies to strikes made by criminal defendants); Edmonson v. Leesville Concrete Co., 500 U.S. 614, 631 (1991) (Batson applies in civil cases). The Batson regime also applies in cases of sex-based peremptory challenges. J.E.B. v. Alabama ex rel. T.B., 511 U.S 127, 145 (1994).

171. Batson, 476 U.S. at 97.

172. Id. at 89 (quoting United States v. Robinson, 421 F. Supp. 467, 473 (D. Conn. 1976)).

173. As noted above, another example of this occurs when courts prevent legislatures from using race as a factor even when it genuinely is the lowest-cost and most efficient proxy for a characteristic Congress might legitimately wish to legislate on. See supra notes 119-20 and accompanying text.

174. See Robar v. LaBuda, 921 N.Y.S.2d 710, 718 (App. Div. 2011) (holding that, while hunting is a constitutionally protected activity, Batson nonetheless does not prevent striking a juror due to their exercise of that activity).

175. See Swain v. Alabama, 380 U.S. 202, 221 (1965) (confirming that lawyers "may include [jurors'] group affiliations" in making the decision to utilize a peremptory strike), overruled by Batson, 476 U.S. 79.

176. Batson, 476 U.S. at 138 (Rehnquist, J., dissenting). 
case. ${ }^{177} \mathrm{~A}$ world where race is treated the same as any other "irrelevant" characteristics is not one in which race is never used at all. Rather, it represents a determination that the usages of race are sufficiently idiosyncratic that we don't think they represent a severe threat to a just social order. Individualized use of race - as in by persons making peremptory strikes of jurors-is perfectly okay, the same as if one struck a juror because one didn't like their hairstyle. ${ }^{178}$

Though peremptory challenges can partially simulate a world in which race has become indistinguishable from other identity axes, it cannot do so entirely. The debate over Batson remains highly race conscious. ${ }^{179} \mathrm{In}$ part, this is because it is difficult to imagine what it would look like for such a fraught identity to completely recede into normalcy - essentially, an America that has collectively forgotten what race once meant. Is there any example of something like that occurring?

A surprising analogy might exist with respect to the treatment of hereditary preferences and the Titles of Nobility Clauses. ${ }^{180}$ In 2006, Carlton F.W. Larson made the provocative argument that the Titles of Nobility Clauses forbid legacy preferences in public university admissions. ${ }^{181}$ In doing so, he had to contend with the widespread notion that the bar on nobility titles is the paradigmatic example of a crystal-clear constitutional clause, ${ }^{182}$ which today could only be invoked by "cranks and misfits." 183 Legacy preferences, for their part, are seen as a quintessential "easy case" -at least as far as constitutional law is concerned. The plaintiffs in the Michigan affirmative-action case quickly conceded that legacy preferences for alumni were constitutional, ${ }^{184}$ and Justice Thomas likewise distinguished legacy preferences from

177. Georgia v. McCollum, 505 U.S. 42, 60-61 (1992) (Thomas, J., concurring in judgment) ("I am certain that black criminal defendants will rue the day that this Court ventured down this road that inexorably will lead to the elimination of peremptory strikes. . . Simply stated, securing representation of the defendant's race on the jury may help to overcome racial bias and provide the defendant with a better chance of having a fair trial."); Edmonson v. Leesville Concrete Co., 500 U.S. 614, 644 (1991) (Scalia, J., dissenting) ("The effect of today's decision . . . will be ... that the minority defendant can no longer seek to prevent an allwhite jury, or to seat as many jurors of his own race as possible. ... So in criminal cases, today's decision represents a net loss to the minority litigant.").

178. But see McCrea v. Gheraibeh, 669 S.E.2d 333, 335 (S.C. 2008) (holding that striking a juror for wearing dreadlocks did not constitute a race-neutral rationale).

179. See supra note 177.

180. U.S. CONST. art. I, $\S 9$, cl. 8 ("No Title of Nobility shall be granted by the United States . . . "); U.S. ConsT. art. I, § 10, cl. 1 ("No state shall . . grant any Title of Nobility.").

181. Carlton F.W. Larson, Titles of Nobility, Hereditary Privilege, and the Unconstitutionality of Legacy Preferences in Public School Admissions, 84 WASH. U. L. REV. 1375 (2006). More than twenty years earlier, Richard Delgado made a similar, though broader, plea for a revitalized Titles of Nobility Clause jurisprudence. Richard Delgado, Inequality "From the Top": Applying an Ancient Prohibition to an Emerging Problem of Distributive Justice, 32 UCLA L. REV. 100 (1984).

182. See Diane P. Wood, Our 18th Century Constitution in the 21st Century World, 80 N.Y.U. L. REV. 1079, 1105 (2005) (distinguishing the Titles of Nobility Clauses from the majority of constitutional doctrines, which, she claims, invite serious legal contestation).

183. Larson, supra note 181, at 1379 ("Titles of nobility? Surely only cranks and misfits invoke the Nobility Clauses in constitutional argument.").

184. Transcript of Oral Argument at 14, Grutter v. Bollinger, 539 U.S. 306 (2003) (No. 02-241). 
racial ones as the sort of preferential treatment that is clearly constitutionally permissible. ${ }^{185}$

Why does the Titles of Nobility Clause argument against legacy preferences strike most of us as intuitively ridiculous? One answer is that legacy preferences don't carry with them a traditional noble title, such as duke or countess. ${ }^{186}$ But the bigger issue is that the idea of a true American aristocracy seems absurd in the twenty-first century. The idea of noble families and royal bloodlines is preposterous. Unlike the eighteenth-century Europe that America was attempting to distinguish itself from, a system of formal hereditary privilege is not today a significant site of political and social conflict and controversy. ${ }^{187}$

But this was not always the case. At the time of the founding, the prospect of a hereditary aristocratic elite was a serious and salient threat. Consequently, Larson contends that the Titles of Nobility Clauses, far from being narrow and mostly extraneous prohibitions, were originally understood in broad, prophylactic terms - barring any sort of preference based on ancestry. ${ }^{188} \mathrm{He}$ recounts the controversy over the 1783 creation of the Society of the Cincinnati, an organization for Continental Army officers. ${ }^{189}$ Today, this sort of fraternal order would pass with little notice, and it might not have been objectionable in the late eighteenth century either, except that membership passed down to the officers' heirs. ${ }^{190}$ Membership did not exactly lead to a lifetime of privilege and luxury; it carried with it "little more than ... a hereditary right to wear a ribbon." ${ }^{191}$ Nonetheless, the hereditary nature of the order caused a torrent of objections to pour out: it was "an hereditary peerage," 192 "contrary to the confederation of the United States, and the spirit of the constitution of this commonwealth," 193 and a "dangerous" group that was "generative of suspicion, jealousy, division and domestick [sic] discord." 194 These objections - which were made with

185. Grutter, 539 U.S. at 368 (Thomas, J., concurring in part and dissenting in part).

186. But see Larson, supra note 181, at 1379-81 (rejecting the notion that this clause was historically understood to apply simply to particular titles).

187. Jack M. Balkin, Constitutional Redemption: Political Faith in an Unjust WORLD 22 (2011) ("[S]o effective was the social transformation brought on by the American Revolution that these [nobility] clauses soon became superfluous, a distant echo of a world and a form of social inequality entirely strange to us.").

188. Larson, supra note 181, at 1383-408; see infra Part III.B (defending the use of prophylactic bans in situations where the relevant conflict is extremely robust and the likelihood the underlying classification will be used for malign purposes is strong).

189. Larson, supra note 181, at 1387-95. At this time, of course, America was governed by the Articles of Confederation, which contained its own analogous clause barring titles of nobility. ARTICLES OF CONFEDERATION OF 1781, art. VI, para. 1 (prohibiting "the United States in congress assembled, or any of [the states]" from granting "any title of nobility").

190. Larson, supra note 181, at 1387-88.

191. Id. at 1400.

192. "Cassius" [Aedanus Burke], Considerations on the Society or Order of Cincinnati 7 (Charleston, A. Timothy 1783) (emphasis omitted).

193. Letter from Henry Knox to George Washington (Feb. 21, 1784), in 1 THE PAPERS OF George Washington: Confederation Series 142, 143 (W.W. Abbot \& Dorothy Twohig eds., 1992) (quoting an act of the Massachusetts Senate).

194. Extracts from the Speech of the Governor of South Carolina to the General Assembly, SAlem GazeTte, Apr. 8, 1784, at 3. 
specific reference to the Articles of Confederation's proscription on titles of nobility—surfaced across political and partisan lines, unifying widely divergent American statesmen in their opposition to the order. ${ }^{195}$

In the eighteenth century, the prospect of a hereditary aristocracy that would represent a systematic deviation from liberal, egalitarian norms was not something hypothetical-it was something all Americans would be familiar with as an organizing principle in England as well as continental Europe. Because the danger was very real, Americans responded by crafting a broadly prophylactic constitutional norm guarding against any sort of hereditary privilege. "How would these Americans have reacted if the federal government or a state had opened and funded an exclusive university to which admission was linked, even in part, to hereditary privilege? ... [T] he answer is obvious - they would have resisted it with every fiber of their being." 196

Today, the prospect of a true familial aristocracy seems remote, and so there is no need for such drastic measures. Legacy preferences represent an extremely isolated and idiosyncratic usage of heredity as part of the allocation of social privileges. This is not to say that legacy preferences are not controversial—of course they are. ${ }^{197}$ But they are not met with the full force and fury of constitutional law as they apparently would have been at the time of the nation's founding. ${ }^{198}$ For better or for worse, they have been devolved back into "normal" politics. ${ }^{199}$ Legacy preferences may be wrong, but they do not run the risk of recreating a European aristocracy, and thus, constitutionally speaking, we do not treat them that way. ${ }^{200}$ The form of social conflict that gave rise to the Titles of Nobility Clauses has disappeared nearly entirely; hence, the sporadic reemergence of hereditary preferences in the present day does not carry with it a blanket proscription akin to strict scrutiny.

It is possible race could see the same evolution - with the history of racial strife

195. Larson, supra note 181, at 1400 ("The Society was little more than a private fraternity of retired public officials with a hereditary right to wear a ribbon. Yet it was denounced as illegitimate and inconsistent with the Articles of Confederation by people who disagreed about almost everything else." (footnote omitted)).

196. Id.

197. See William G. Bowen, Martin A. Kurzweil \& Eugene M. Tobin, Equity and EXCELlENCE IN AMERICAN Higher EdUCATION 1 (2005) (reporting that three-quarters of Americans disapprove of legacy preferences in college admissions).

198. Fourteenth Amendment challenges to allegedly nepotistic state laws have also foundered. See Kotch v. Bd. of River Port Pilot Comm'rs, 330 U.S. 552, 563-64 (1947) (upholding a Louisiana statute which effectively restricted the licensing of new river pilots only to friends and relatives of existing pilots); Ellebracht v. Police Bd. of the Metro. Police Dep't, 137 F.3d 563, 566 (8th Cir. 1998) (turning back an equal-protection challenge even where concededly "[f]amilial and political influence may have played some role in the promotion process"). But see Backlund v. Hessen, 104 F.3d 1031, 1033-34 (8th Cir. 1997) (holding that Kotch still requires that a rational basis be shown for nepotistic classifications).

199. See Schraub, Unsuspecting, supra note 5, at 367 (arguing that the entire point of suspect-classification doctrine is for the protected groups to eventually be able to return to the normal "rough-and-tumble" of standard democratic politics).

200. Cf. FORD, supra note 56, at 159 (conceding that appearance discrimination exists but discounting the case for treating it like racial discrimination because it has not historically or contemporaneously been as severe as racial strife and because it has not systematically prevented the disadvantaged group from securing political or economic success). 
and conflict receding so far into the background that it is nearly forgotten. ${ }^{201}$ In this case, race would appear in American public life extremely rarely, and when it did it would be seen more as a perplexing idiosyncrasy than as a grave threat to the social order. It might still prove controversial, just as legacy preferences are controversial, and just as an employer who openly stated she did not wish to hire an "ugly" employee might be controversial. ${ }^{202}$ But in all cases, this controversy would not be seen as rising to the hypertrophic level necessitating something like strict scrutiny.

\section{Dialing Race Back-According Race Intermediate Scrutiny}

The story laid out above-whereby race recedes so far from the public eye that we effectively forget it ever was a problem - may seem implausible. But it is hardly necessary to take an all-or-nothing approach. The public salience of race exists upon a continuum - even if we find it hard to envision that the risk of racial strife will entirely disappear such that it approximates the risk of European feudalism, we might still believe that it is no longer so central to American life that it requires the most stringent oversight available in American constitutional law. Another alternative is to begin slowly dialing back the special protections race receives. ${ }^{203}$ American constitutional law already possesses an intermediate tier between strict scrutiny and the baseline of rational basis. ${ }^{204}$ In contrast to strict scrutiny, which requires that the challenged statute be "narrowly tailored" in pursuit of a "compelling governmental interest[]," 205 intermediate scrutiny is more relaxed with regard to both means and ends. To satisfy intermediate scrutiny, the law in question "must serve important governmental objectives and must be substantially related to achievement of those objectives. ${ }^{206}$

201. See Barnes et al., supra note 58, at 978 (noting the possibility that race could become something noticed but entirely benign, while implying that this is not an accurate assessment of the status quo).

202. FORD, supra note 56, at 134-39 (detailing a San Francisco hotel which specifically vetted employment candidates on basis of appearance and the debate over a Santa Cruz ordinance banning appearance-based discrimination).

203. While others have proposed applying intermediate scrutiny to certain types of (benign) racial classifications, see supra note 6 , no one, to my knowledge, has contemplated transitioning all racial classifications to this standard.

204. See Craig v. Boren, 429 U.S. 190, 197 (1976) (establishing what would come to be known as intermediate scrutiny as a middle tier applied to sex classifications).

205. Adarand Constructors, Inc. v. Pena, 515 U.S. 200, 227 (1995).

206. Craig, 429 U.S. at 197. The language of this test has varied somewhat from case to case. See, e.g., United States v. Virginia, 518 U.S. 515, 531 (1996) (stating that the justification for a sex classification measured under intermediate scrutiny must be "exceedingly persuasive" (quoting Miss. Univ. for Women v. Hogan, 458 U.S. 718, 724 (1982))); Madsen v. Women's Health Ctr., 512 U.S. 753, 791 (1994) (Scalia, J., concurring in the judgment in part and dissenting in part) (criticizing a reformulation of the intermediate-scrutiny language as establishing “intermediate-intermediate scrutiny"); City of Cleburne v. Cleburne Living Ctr., Inc., 473 U.S. 432, 441 (1985) (observing that a legislative classification reviewed under intermediate scrutiny must be "substantially related to a sufficiently important governmental interest"); see also Jay D. Wexler, Defending the Middle Way: Intermediate Scrutiny as Judicial Minimalism, 66 GEO. WASH. L. REV. 298, 301 (1998) (observing that the intermediate 
As noted above, the mechanics by which particular classifications are allocated strict, intermediate, or rational-basis scrutiny are notoriously opaque. ${ }^{207}$ Nonetheless, the organizing principle behind the entire doctrine strongly implies that increased political integration should begin a process of ratcheting down the "extraordinary" political protection represented by strict scrutiny. ${ }^{208}$ Insofar as the ultimate goal of all discrimination law can be described as integrating racial minorities into "normal" politics - the failure of which prompts heightened judicial solicitude of minorities in the first place ${ }^{209}$ - it stands to reason that the increased standing of racial minorities in American society should eventually lead racial classifications to become normalized with respect to the degree of judicial scrutiny they are afforded.

Note that making this observation does not mean that strict scrutiny was never the proper standard by which to evaluate racial classifications, or even that it is not the proper standard today. Rather, what it reveals is that the application of strict scrutiny to racial classifications necessarily requires a particular evaluation of race in America —one in which race acts as a serious, constant, and systematic source of political, social, or economic deprivation (in other words, one in which we are quite far from being post-racial). The state of affairs in the Jim Crow South clearly met this burden; our current status quo may or may not. It is the outcome of this appraisal that then warrants a series of race-conscious interventions into legislative activity - such as demanding that any racial classifications meet the high burden of being narrowly tailored to a compelling state interest. But there is a hydraulic relationship at work - the more fervently we are willing to argue we are "post-racial," the less justifiable it becomes to continue according race the exceptional protections represented by strict scrutiny.

How would our race jurisprudence change if intermediate scrutiny were the governing doctrine detailing governmental use of race? In many of the highest profile cases, the likely answer is, "It wouldn't." 210 Many of the historical cases—-such as Brown v. Board of Education ${ }^{211}$ or Loving v. Virginia ${ }^{212}$-would not change, because strict scrutiny was clearly the appropriate method of approach for racial classification at that time period. ${ }^{213}$ But suppose a contemporary legislature, operating under

scrutiny test and language have "been particularly vulnerable to manipulation by the Supreme Court").

207. See supra note 85 and accompanying text.

208. See San Antonio Indep. Sch. Dist. v. Rodriguez, 411 U.S. 1, 28 (1973).

209. United States v. Carolene Products Co., 304 U.S. 144, 152 n.4 (1938); see supra notes 87-89 and accompanying text.

210. In Metro Broadcasting, Inc. v. FCC, Justice Kennedy predicted that permitting intermediate scrutiny to control even benign racial classifications "would validate . . . any number of future racial classifications the Government may find useful." 497 U.S. 547, 633-34 (1990) (Kennedy, J., dissenting). However, he did not cite a single example save Korematsu v. United States, 323 U.S. 214 (1943) - a case which, as Justice Kennedy concedes, affirmed a racial classification via strict scrutiny. Metro Broad., 497 U.S at 633.

211. 347 U.S. 483 (1954).

212. 388 U.S. 1 (1967).

213. There is a near tautology here - the very fact that a society has antimiscegenation laws, or pervasive de jure school segregation, is the strongest possible proof that a society is so deeply infected with racist sentiment so as to require constant, extraordinary judicial oversight akin to strict scrutiny. Strict scrutiny is appropriate in Loving because having a law 
intermediate-scrutiny review, did pass a law mandating segregation of schools or barring interracial marriage. It seems quite unlikely that such laws would be deemed to either be in pursuit of an important governmental objective or be substantially tied to such a purpose. ${ }^{214}$ In United States v. Virginia ${ }^{215}$ the Supreme Court struck down sex-segregated educational facilities in the state of Virginia under intermediatescrutiny review. ${ }^{216}$ In the context of gay-marriage litigation, few believed that restricting marriage to heterosexual couples could survive heightened scrutiny. ${ }^{217}$ Many, if not all, of the most egregious racial injustices would be blocked under heightened scrutiny as much as they are under strict scrutiny.

In other contexts, the shift would have little impact because strict scrutiny has never been held to apply in the first place. The use of race as part of a criminal suspect profile, for instance, has never been considered a "racial classification" subject to strict scrutiny. ${ }^{218}$ This carve-out has been harshly criticized, ${ }^{219}$ but for better or for

barring interracial marriage is symbolic of the conditions whereby strict scrutiny can be justified.

214. See supra note 206 and accompanying text.

215. 518 U.S. 515 (1996).

216. Id. at 519 .

217. This is now mostly a moot issue, as Obergefell $v$. Hodges struck down bans on samesex marriage without referencing the issue of tiered scrutiny at all. 135 S. Ct. 2585 (2015); see also Schraub, Siren Song, supra note 5, at 864-67 (describing the implications of the Court declining to rely on strict scrutiny for its decision). However, lower courts which applied intermediate scrutiny universally concluded that same-sex marriage bans could not stand. See, e.g., Kerrigan v. Comm'r of Pub. Health, 957 A.2d 407, 476-81 (Conn. 2008); Varnum v. Brien, 763 N.W.2d 862, 896-906 (Iowa 2009). Once the federal government concluded that intermediate scrutiny properly applied to sexual-orientation-based classifications, it likewise found that the federal Defense of Marriage Act was incontestably unconstitutional under that standard of review. Letter from Eric Holder, U.S. Att'y Gen., to John Boehner, Speaker, U.S. House of Representatives (Feb. 23, 2011), https://www.justice.gov/sites/default/files/oip /legacy/2014/07/23/02-23-2011.pdf [https://perma.cc/E32U-K25J]. Lower courts did uphold restrictions on gay marriage, but only after finding that rational basis is the proper standard of review. See, e.g., Conaway v. Deane, 932 A.2d 571, 606 (Md. 2007) (declining to apply heightened scrutiny and upholding the prohibition on gay marriage); Hernandez v. Robles, 855 N.E.2d 1, 10 (N.Y. 2006) (same).

218. See, e.g., Brown v. City of Oneonta, 221 F.3d 329, 337-38 (2d Cir. 2000) ("In acting on the description provided by the victim of the assault - a description that included race as one of several elements - defendants did not engage in a suspect racial classification that would draw strict scrutiny. The description, which originated not with the state but with the victim, was a legitimate classification within which potential suspects might be found."); United States v. Avery, 137 F.3d 343, 354 n.5 (6th Cir. 1997) (explaining that "the decision to investigate someone [of a particular race] based on a tip from a source outside the police organization" does not violate the Equal Protection Clause); United States v. Travis, 62 F.3d 170, 174 (6th Cir. 1995) ("Obviously race or ethnic background may become a legitimate consideration when investigators have information on this subject about a particular suspect.").

219. See, e.g., R. Richard Banks, Race-Based Suspect Selection and Colorblind Equal Protection Doctrine and Discourse, 48 UCLA L. REv. 1075, 1109 (2001) ("To conclude that race-based suspect descriptions should not be treated as a racial classification because they seem useful or justified would be to engage in precisely the sort of threshold substantive evaluation that the doctrinal structure forecloses, and that the Supreme Court has explicitly 
worse strict scrutiny does not occupy the field in this area of law. "Disparate impact" claims are another area which have not been governed by strict scrutiny-mere racially disproportionate impacts, absent discriminatory purposes, are not the subject of constitutional proscription. ${ }^{220}$ Laws which specifically target race-conscious policy making by college administrators likewise do not appear to fall under strict scrutiny's gaze. ${ }^{221}$

One arena which would probably see a substantial change would be in "benign" racial classifications - those designed to foster racial inclusion and equality rather than stymie it. In Metro Broadcasting, Inc. v. FCC, the Supreme Court held that benign racial classifications were subject to intermediate, rather than strict, scrutiny. ${ }^{222}$ This decision was soon reversed in Adarand Constructors, Inc. v. Pena, which created a blanket policy applying strict scrutiny in all cases. ${ }^{223}$ Neither the dissenters in Metro Broadcasting nor the majority in Adarand argued that the challenged affirmative action programs should fail under intermediate scrutiny - their claim was purely that this was an inappropriate standard of review. ${ }^{224}$ The action in these cases was entirely along the heightened/strict scrutiny axis - consequently, it seems likely that affirmative action programs would survive constitutional scrutiny.

This conclusion, of course, does not mean that intermediate scrutiny is normatively superior to strict scrutiny as a doctrinal framework for race cases. After all, many believe that affirmative action programs are deeply wrongful (if not dangerous). ${ }^{225}$ For these people, a doctrinal approach which prohibits de jure segregation and race-conscious integration efforts would be greatly preferable to one which only bars the former. However, given the ever-expanding doctrinal incoherency between how the courts describe the criterion for becoming a suspect class and how they depict the current state of racial affairs, ${ }^{226}$ it does indicate that the seemingly permanent

disavowed." (emphasis in original)).

220. Washington v. Davis, 426 U.S. 229, 239 (1976) ("[O]ur cases have not embraced the proposition that a law or other official act, without regard to whether it reflects a racially discriminatory purpose, is unconstitutional solely because it has a racially disproportionate impact." (emphasis in original)); Vill. of Arlington Heights v. Metro. Hous. Dev. Corp., 429 U.S. 252, 264-65 (1977) (applying the Davis disparate-impact test, as opposed to strict scrutiny, in a case alleging disparate impact).

221. Schuette v. Coalition to Defend Affirmative Action, 134 S. Ct. 1623, 1625 (2014).

222. Metro Broad., Inc. v. FCC, 497 U.S. 547, 564-65 (citing Fullilove v. Klutznick, 448 U.S. 448, 519 (1980) (Marshall, J., concurring in judgment)).

223. 515 U.S. 200, 227 (1995) ("[W]e hold today that all racial classifications . . must be analyzed by a reviewing court under strict scrutiny. . . . To the extent that Metro Broadcasting is inconsistent with that holding, it is overruled.").

224. Id. at 226-27 (deciding to overrule Metro Broadcasting on the grounds that intermediate scrutiny is never appropriate to apply to racial classifications); Metro Broad., 497 U.S. at 603 (O'Connor, J., dissenting) ("The Court's application of a lessened equal protection standard ... finds no support in our cases or in the Constitution."); id. at 633 (Kennedy, J., dissenting) (critiquing the majority for "abandoning strict scrutiny").

225. See, e.g., Metro Broad., 497 U.S. at 609 (O’Connor, J., dissenting) (““"Benign” racial classification' is a contradiction in terms. Governmental distinctions among citizens based on race or ethnicity, even in the rare circumstances permitted by our cases, exact costs and carry with them substantial dangers.").

226. See supra notes $99-101$ and accompanying text. 
elevation of racial classifications to strict-scrutiny status is motivated not by any formalistic requirements, but rather by a normative commitment to a particular, colorblind approach to racial policymaking. ${ }^{227}$ In other words, affirmative action programs are not usually unconstitutional because they fail strict scrutiny, rather, strict scrutiny is applied to affirmative action programs because it ensures that such policies are usually struck down.

Such results-oriented decisionmaking is indicative that the Justices in question consider questions of race and racial policy as being possessed of exceptional normative importance. Otherwise, there would be no need to contort the doctrine to fit their preferred policy prescriptions. But the very fact that these normative commitments run deep enough to move a Supreme Court majority is difficult to square with the belief that race is meaningfully receding in public importance. The decision to maintain strict scrutiny in these cases - despite the fact that doing so appears to inject race into American jurisprudence in a manner deeply incompatible with post-racial ambitions - in effect represents a concession that America never will rise beyond race and that the risks of eliminating a flat prophylactic rule remain, and perhaps always will remain, too high to begin the process of removing race from its doctrinally superordinate position. It is to this possibility that I now turn.

\section{B. Strict Scrutiny as a Second-Best Solution}

If strict scrutiny is fundamentally inconsistent with post-racial ambitions, why ever have it? One answer is that strict scrutiny is justified whenever any usage of race will have (or likely have) predominantly negative effects. Here, strict scrutiny serves a prophylactic function - barring the use of race in (nearly) all cases based on a considered judgment that the risks of mistakenly permitting malevolent (in intent or effect) classifications are high enough to warrant a virtual per se rule against them. ${ }^{228}$ This was the argument made by Justice O'Connor in City of Richmond $v$. J.A. Croson Co. ${ }^{229}$ : without "searching judicial inquiry into the justification for such race-based measures, there is simply no way of determining what classifications are 'benign' or 'remedial' and what classifications are in fact motivated by illegitimate notions of racial inferiority or simple racial politics."230

227. See, e.g., Book Note, Justice Thomas's Inconsistent Originalism, 121 HARV. L. ReV. 1431, 1435-36 (2008) (reviewing Clarence ThOMAs, My GrandFATHER's SON: A MEMOIR (2007)) (arguing that Justice Thomas's race jurisprudence is inconsistent with his broader originalist philosophy and is better explained by a series of normative commitments he has regarding the perils of permitting any usage of race in public life).

228. Brian K. Landsberg, Safeguarding Constitutional Rights: The Uses and Limits of Prophylactic Rules, 66 TENN. L. REV. 925, 941-42 (1999) (describing the Rehnquist Court's restrictions on race-conscious affirmative action as prophylactic measures); David A. Strauss, The Ubiquity of Prophylactic Rules, 55 U. CHI. L. REV. 190, $204-05$ (1988) ("Strict scrutiny ... is a relatively rigid rule adopted on the ground that the government is likely to act unlawfully and the courts will have a difficult time detecting its unlawful conduct."); see also Schraub, Unsuspecting, supra note 5, at 406-07 (analogizing tiered-scrutiny review to a lottery).

229. 488 U.S. 469 (1989).

230. Id. at 493 (plurality opinion); see also Michael Klarman, An Interpretive History of 
Any sort of ambivalence regarding the permissibility of race-conscious actions runs the risk of showing "deference to discriminators." ${ }^{231}$ If there are very few persons who are attempting to discriminate, this risk may be negligible. If racism is rampant in society, by contrast, it is far more likely that the average use of race by a decisionmaker will be malignant in motive or effect (regardless of whether it is publicly characterized as salutary or hostile). In situations where the political use of race is solely (or nearly exclusively) to divide and subordinate, strict scrutiny makes sense even recognizing that some truly beneficent usages may be foreclosed. ${ }^{232}$ And indeed, the same psychological research which warned about the potentially counterproductive effects of asking persons to "suppress" race 233 also noted that such strategies tend to be more effective - or at least, more likely to see gains outweighing losses-amongst persons who are relatively high in prejudice. ${ }^{234}$ After all, if the worry is that suppressing race also involves suppressing uses of race that may help overcome, rather than buttress, racial prejudice, highly prejudiced individuals have the "advantage" of possessing fewer positive racial ideals in the first place. ${ }^{235}$

The above case, of course, rests upon a specific appraisal about the salience of race in American society. It is an appraisal that is clearly on the mark as applied to certain chapters of our history, such as Jim Crow. But by its terms it is temporally

Modern Equal Protection, 90 Mich. L. REv. 213, 312 (1991) (“Justice O’Connor's majority opinion portrayed strict scrutiny as a prophylactic against malevolent racial classifications successfully masquerading as benevolent ones.”); Primus, supra note 79, at 504 (explaining the "administrative intuition ... that it is much easier to implement a rule that subjects all racial classifications to strict scrutiny than a rule that subdivides racial classifications, treating some one way and others differently"); Van Alstyne, supra note 1, at 797 (declaring the sort of inquiry necessary to distinguish benign and malign racial classifications to be "a sieve that encourages renewed race-based laws, racial discrimination, racial competition, racial spoils systems, and mere judicial sport").

231. Darren Lenard Hutchinson, The Majoritarian Difficulty: Affirmative Action, Sodomy, and Supreme Court Politics, 23 LAw \& INEQ. 1, 62-63 (2005) (arguing that the "deference" the Supreme Court showed to affirmative action programs in Grutter could thus ultimately hinder social-justice aims); see also Ian F. Haney López, The Social Construction of Race: Some Observations on Illusion, Fabrication, and Choice, 29 HARV. C.R.-C.L. L. REV. 1, 19 (1994) ("To acknowledge race is to leave open the possibility — indeed the certainty - that this acknowledgment will at times be turned to racism's service.").

232. Cf. David Schraub, Sticky Slopes, 101 CALIF. L. REV. 1249, 1287-90 (2013) (observing that civil rights advocates may have adopted colorblindness as an argumentative strategy because it was best suited to the exigencies of the moment, while still recognizing it might pose a barrier to necessary future reforms).

233. See supra notes $148-53$ and accompanying text.

234. See Vorauer \& Turpie, supra note 152, at 395 (noting that high-prejudice persons who are consciously attempting to police their own behavior tend to "shine," rather than "choke," in interpersonal relations with outgroups). But see Monteith et al., supra note 152, at 78-79 (suggesting that high-prejudice persons may be more likely to consider stereotypes when under instructions to avoid them because they have developed fewer mechanisms for avoiding their use).

235. Vorauer \& Turpie, supra note 152, at 385 ("The case for higher-prejudice persons is apt to be somewhat different. As these individuals are unlikely to be highly proficient at the favorable treatment of outgroup members, there may be relatively little routinized positive behavior to disrupt." (footnote omitted)). 
variant - if the malignant influence of race recedes, then the need for prophylactic measures recedes along with it. ${ }^{236}$ To recognize strict scrutiny as the best legal doctrine for combating the conditions prevailing in America at the time of Jim Crow is not to endorse it in perpetuity. ${ }^{237}$

So what does it mean to entrench strict scrutiny as a permanent feature of our jurisprudence? It is to say that the pervasiveness of racial prejudice is an indelible state of affairs - race will perpetually be too dangerous to use, and it will always stoke the fires of racialized resentment and conflict. ${ }^{238}$ This position, that racism may be a permanent feature of American political life, is most associated with critical race theory founder Derrick Bell. ${ }^{239}$ However, there are some indications that persons whose perspectives on race diverge drastically from Professor Bell's are similarly skeptical of ever dissolving the terrifying moral force of race. Justice Scalia warned his colleagues that any departure from the colorblind principle necessarily involves "play[ing] with fire." 240 Race is and ever will be perpetually dangerous, and this is something America will never transcend.

More systematically, this perspective has deep roots in conservative Black political thought. The mid-twentieth-century Black conservative writer George Schuyler opened his autobiography by asserting that racial disadvantage is "an unalterable circumstance" in a world dominated by White people. ${ }^{241}$ "[T] here is, and always will be, a color caste system in the United States"; hence, Black political strategy should "concentrate on how to best survive and prosper within that system." 242 From that

236. See Landsberg, supra note 228, at 972-73 ("Risks may change over time. A prediction founded on prevailing social attitudes becomes unreliable as those attitudes evolve."); Reva B. Siegel, Equality Talk: Antisubordination and Anticlassification Values in Constitutional Struggles over Brown, 117 HARV. L. REV. 1470, 1515 n.158 (2004) (observing that the position of civil rights organizations regarding the collection of racial data in areas such as crime rates and employment statistics has shifted depending on whether they believed such data was more likely to be used for discriminatory or remedial purposes).

237. See Barnes et al., supra note 58, at 997-98 (noting that colorblindness "was a powerful progressive tool" in a society mired in, or just emerging from, Jim Crow segregation but that its valence has changed to become a tool for preserving, rather than challenging, an unjust status quo); Schraub, supra note 232, at 1290-96 (noting how an unambiguous victory for a social group at one point in time can act to retard its future ambitions).

238. Reva B. Siegel, From Colorblindness to Antibalkanization: An Emerging Ground of Decision in Race Equality Cases, 120 YALE L.J. 1278, 1300-03 (2011) (explaining the emergent "antibalkanization" view of racial questions by the Supreme Court, which limits the use of race-conscious remedies because it believes that the usage of race provokes racial resentment and controversy that outweighs any remedial benefits); Siegel, supra note 117, at 787 (arguing that the primary determinant of when the Court restricts the use of race is whether they believe it will contribute to racial "balkanization").

239. See generally Derrick Bell, Faces at the Bottom of the Well: The Permanence of RACiSM (1992); Derrick Bell, Racial Realism, 24 ConN. L. Rev. 363 (1992).

240. City of Richmond v. J.A. Croson Co., 488 U.S. 469, 527 (1989) (Scalia, J., concurring in judgment) ("When we depart from [the colorblind] principle we play with fire, and much more than the occasional DeFunis, Johnson, or Croson burns.").

241. George S. SCHUYLER, BLACK AND CONSERvative 1 (1966) (concluding that "the lifetime endeavor of the intelligent Negro is how to best be reasonably happy though colored").

242. Id. at 121-22. 
vantage point, it makes perfect sense to promote a blanket rule barring the use of race in any and all cases.

Likewise, this view seems to accord with Justice Thomas's views on race in America. ${ }^{243}$ Justice Thomas harbors no delusions that racism has been extinguished in American life. To the contrary, he has been very forthright in recounting the considerable amount of racism he has personally experienced and overcome to reach his current position, ${ }^{244}$ racially motivated hostility which continues to inflect the public's perception of his performance as a Supreme Court Justice. ${ }^{245}$ But for Thomas, this belief in the continuing power of racism in America counsels greater wariness about official use of race. Early in his life, he was heavily influenced by a law school friend who asked him, "Clarence, as a member of a group that has been treated shabbily by the majority in this country, why would you want to give the government more power over your personal life?"246 In his Parents Involved concurrence, Thomas warned his colleagues that "if our history has taught us anything, it has taught us to beware of elites bearing racial theories." ${ }^{247}$ These claims do not rely on our progress at eradicating race as a meaningful social problem but on deep skepticism that we have done so or ever will do so.

This is a perfectly cohesive position. But we need to be clear about what we are giving up. Post-racialism, as an aspiration, cannot survive a world in which racism is a permanent feature of our politics. Strict scrutiny in perpetuity effectively states that race is, in fact, something we'll never get beyond.

\section{Race Without Fear}

To this point, my focus has been primarily on the applications and limitations of

243. Angela Onwuachi-Willig, Just Another Brother on the SCT?: What Justice Clarence Thomas Teaches Us About the Influence of Racial Identity, 90 IowA L. REV. 931 (2005) (locating Justice Thomas's jurisprudence within the larger corpus of Black conservative thought). 244. See, e.g., Nomination of Judge Clarence Thomas To Be Associate Justice of the Supreme Court of the United States: Hearing Before the S. Comm. on the Judiciary, 102d Cong. pt. 4, at 157 (1993) (statement of Clarence Thomas) (accusing his confirmation process as resembling a "high-tech lynching"); THOMAS, supra note 227, at 250 (describing the "controvers[y]" over his tenure as head of the Equal Employment Opportunity Commission as stemming from his "refus[al] to bow to the superior wisdom of the white liberals who thought they knew what was better for blacks"); see also KEVIN MERIDA \& MichaEl A. FLETCHER, Supreme Discomfort: The Divided Soul of Clarence Thomas 98 (2007) (describing Thomas's experiences with racism as a seminary student).

245. See Tony Mauro, Clerks: Minority Ranks Rise, Legal Times, Oct. 16, 2000, at 10 (quoting Justice Thomas as saying, "Because I am black, it is said automatically that Justice Scalia has to do my work for me. That goes with the turf. I understand that deal.").

246. Thomas, supra note 227 , at 73 . The question, Thomas later reflected, "stopped me cold." Id.

247. Parents Involved in Cmty. Sch. v. Seattle Sch. Dist. No. 1, 551 U.S. 701, 780-81 (2007) (Thomas, J., concurring). Consider as a recent example Hernstein and Murray's notorious book The Bell Curve. Richard J. Herrnstein \& Charles Murray, The Bell Curve: INTELLIGENCE AND ClASS STRUCTURE IN AMERICAN LiFE 269-315 (1994) (claiming at least some racial differences in innate intelligence, with African Americans scoring one standard deviation below the mean vis-à-vis Whites in IQ tests). 
strict-scrutiny doctrine. There is a deep confusion in strict-scrutiny doctrine-it purports to pursue a post-racial world, but it cannot get us there. As outlined in the previous section, one answer is simply to give up the dream - race will always be with us and always be dangerous, and thus strict scrutiny will always be necessary as a bulwark against it.

This may be coherent, but it is also deeply unsatisfactory. The desire to become post-racial speaks to something very real in the American psyche, and it is not one I think we should cast aside lightly. In this final section, I circle back to our concept of post-racialism and ask, "What exactly are we trying to get "post'?" I argue that the problem which motivates the post-racial impulse is not the category of race itself, but rather, fear of the strife and conflict associated with race. That is what we wish to get beyond - the goal, in Adorno's words, is not necessarily for racial difference to end but for society to be a place where we can be "different without fear." ${ }^{248}$ And there are, and in other contexts the Supreme Court has recognized, alternative paths to that end beyond brute suppression of race as a category.

\section{The Trailblazers: Religion and Indigenous Status}

Fear is an ongoing theme of racial discourse in America. To play with race is to "play with fire." 249 Even the slightest retreat from strict scrutiny puts us back on the path to Korematsu, ${ }^{250}$ or Plessy. ${ }^{251}$ When race enters the discussion, one has to "walk on eggshells," and a single mistake or misstatement carries with it catastrophic consequences. ${ }^{252}$ And because until very recently, race-conscious behavior was "the primary means of maintaining the supremacy of whites, ${ }^{253}$ many Americans are understandably wary about drawing again from that well, even with the most salutary motives. We go to extraordinary, sometimes ridiculous lengths to avoid having to make any conscious acknowledgment of race in public. ${ }^{254}$

248. ADORNO, supra note 61, at 103.

249. City of Richmond v. J.A. Croson Co., 488 U.S. 469, 527 (Scalia, J., concurring).

250. Metro Broad., Inc. v. FCC, 497 U.S. 547, 633-34 (Kennedy, J., dissenting) (declaring that permitting only intermediate scrutiny for benign racial classifications would sanction Korematsu).

251. Parents Involved, 551 U.S. at 773-74 (Thomas, J., concurring) (accusing the dissenters' advocacy of race-conscious integration programs of replicating the logic of Plessy "to a distressing extent"); Van Alstyne, supra note 1, at 797 (permitting the use of race in some contexts "is Plessy v. Ferguson all over again, in new and modish dress").

252. See, e.g., Camille Gear Rich, Decline To State: Diversity Talk and the American Law Student, 18 S. CAL. REV. L. \& Soc. JuST. 539, 563 (2009) (quoting one person as complaining, "Certain things, you know, you just don't say certain things, you can't make, um . . . certain comments or jokes, things that used to be, you know, okay. It makes me feel . . it makes me feel like I am walking around on eggshells all the time, like I might say the wrong thing.").

253. Barbara J. Flagg, "Was Blind, but Now I See”: White Race Consciousness and the Requirement of Discriminatory Intent, 91 MicH. L. REV. 953, 954 (1993).

254. My favorite example of this came while I was watching a boxing match on ESPN2. Boxers are typically identified by the color of their trunks, but in this case both men were wearing the same color trunks as well as the same color gloves. So the audience was dutifully informed that one fighter was wearing red shoes and one was wearing white shoes, and that 
But what we're afraid of isn't some abstraction — "race" — or even the prospect of human beings defining themselves along racial lines. The worry refers to what Neil Siegel calls racial "balkanization": "the extent to which Americans identify as members of separate racial or ethnic groups that view one another with hostility." 255 And the reason this particular axis of differentiation is presumed to be associated with hostile interrelations is because of the very specific history of domination and subjugation that characterized the role of race in American life. ${ }^{256}$

The fact of racial oppression (not just identification) is thus critical. To say that the problem with segregation was simply that state education statutes used the word "Negro" is to badly miss the point. Segregation was wrong because it was part and parcel of a centuries-long structure of massive, race-based oppression. In this, it is hardly alone - regrettably, many identity axes other than race have had similar histories of violence and conflict. Yet in many of these cases, our political responsewhile committed to subduing the fires - has not even remotely approximated the suppressive "strict scrutiny" regime. Religion and indigenous status are two examples of characteristics deeply enmeshed in such histories where courts have been willing, to various extents, to permit government acknowledgment and recognition of the underlying identities.

The story of much of Western social history is one of religious conflict, but the idea of a "religion-blind" Constitution is controversial, at best. ${ }^{257}$ Courts have been far more tolerant of government "noticing" religion in order to rectify substantive inequalities than they have been in racial contexts. ${ }^{258}$ The United States is mandated

the latter also had his name written in small lettering across his waistband. The color commentator then dryly remarked: "He's also the black guy." See BadSpectator, Andrzej Fonfara vs Derrick Findley, YouTuBE (July 21, 2008), https://www.youtube.com/watch?v=01oBAF3IE_w, originally broadcast on ESPN Friday Night Fights (ESPN2 television broadcast July 11, 2008); Chris Lenz, Why I Love Teddy Atlas: A Brief Discussion on Race in Boxing, BLEACHER REP. (July 11, 2008), http://bleacherreport.com/articles/36980-why-i-love-teddy-atlas-a-brief -discussion-on-race-in-boxing [https://perma.cc/LM3E-ADZH].

255. Siegel, supra note 117, at 787 (emphasis added).

256. Richard Lempert, The Force of Irony: On the Morality of Affirmative Action and United Steelworkers v. Weber, 95 ETHICS 86, 88-89 (1984) ("Why does racial discrimination excite us when so many other kinds of discrimination do not? It is because of the way we interpret history, associating racial discrimination with practices that now appear selfevidently evil ....”).

257. See supra notes 62-63 and accompanying text; see also David Schraub, When Separation Doesn't Work: The Religion Clause as an Anti-Subordination Principle, 5 DARTMOUTH L.J. 145 (2007).

258. See Gonzales v. O Centro Espirita Beneficente Uniao do Vegetal, 546 U.S. 418, 439 (2006) (granting the União do Vegetal church a Religious Freedom Restoration Act exemption to laws which would have barred it from importing an ingredient necessary for their sacramental tea); Wisconsin v. Yoder, 406 U.S. 205, 234 (1972) (striking down Wisconsin's mandatory school-attendance law as applied to the Amish); Walz v. Tax Comm'n, 397 U.S. 664, 669 (1970) (describing the "play in the joints" between what the Free Exercise clause requires of government and what the Establishment Clause forbids); Bernadette Meyler, The Equal Protection of Free Exercise: Two Approaches and Their History, 47 B.C. L. REv. 275, 326 (2006). 
to be neutral towards religion, but this is understood as a "benevolent neutrality"259 permitting government to recognize and foster religious observance in ways deeply at odds with a purely formalist paradigm. This benevolence enables government to, for instance, exempt religious properties from $\operatorname{taxation}^{260}$ and certain antidiscrimination provisions ${ }^{261}$ and in general grants legislatures some latitude in accommodating religious practitioners burdened by generally applicable rules. ${ }^{262}$

Unlike the "benign" racial classifications which were asserted to be nonexistent by Justice O'Connor, ${ }^{263}$ courts are up-front in acknowledging the possibility of at least limited governmental recognition of religion and religious needs. And what's more, this treatment is explicitly tied to the historical risk of religious discrimination -in other words, as a legislative tool for mitigating, rather than stoking, the fires of religious conflict. ${ }^{264}$ Cognizant of a severe history of religious discrimination, courts nonetheless are willing to recognize - subject to oversight and limits-the utility of allowing government to pay heed to religious difference in the service of fostering religious pluralism. ${ }^{265}$

The United States's treatment of Native Americans has likewise been characterized by more than its fair share of brutality, yet the jurisprudence surrounding "raceconscious" preferences for Native Americans rather famously diverges from that accorded to racial classifications more generally. ${ }^{266}$ Our categorization of Native Americans is a "conscious" one, treating indigenousness as an independent identity that is explicitly noted and recognized. This differentiation from race (legally speaking) is traceable at least to Cherokee Nation v. Georgia, which designated Indian tribes as "domestic dependent nations." 267 And-in stark contrast to the track of

259. Walz, 397 U.S. at 669.

260. Id. at 680 .

261. Hosanna-Tabor Evangelical Lutheran Church \& Sch. v. EEOC, 132 S. Ct. 694, 709 (2012); Corp. of the Presiding Bishop of the Church of Jesus Christ of Latter-Day Saints v. Amos, 483 U.S. 327, 338-40 (1987). These exemptions, in particular, have grown more controversial as they have begun to be asserted by for-profit corporations who nonetheless claim a religious mission. See generally The Rise of Corporate Religious Liberty (Micah Schwartzman, Chad Flanders \& Zoë Robinson eds., 2016).

262. See Cutter v. Wilkinson, 544 U.S. 709, 713-14 (2005).

263. Metro Broad., Inc. v. FCC, 497 U.S. 547, 609 (1990) (O’Connor, J., dissenting).

264. Walz, 397 U.S. at 673 (casting the tax exemption for religious properties as responsive to the historical risk of governmental "hostility toward religion").

265. See, e.g., Cutter, 544 U.S. at 719-24 (holding that government accommodation for religious practices burdened by generally applicable laws can be permissible so long as it does not privilege one faith practice over another).

266. See Morton v. Mancari, 417 U.S. 535, 555 (1974) (holding that differential treatment of Indians is permissible where it "can be tied rationally to the fulfillment of Congress's unique obligation toward the Indians"). The Supreme Court did attempt to argue that these preferences are not "racial" but political, id. at 553 \& n.24, but this distinction is difficult to swallow given that the challenged policy specifically "required individuals to be both tribal members and have at least one-quarter Indian blood to qualify for the preference," Bethany R. Berger, Reconciling Equal Protection and Federal Indian Law, 98 CALIF. L. REV. 1165, 1185 (2010) (emphasis in original).

267. 30 U.S. (5 Pet.) 1, 17 (1831). 
race - oftentimes the law affirmatively requires Native American tribes to retain a (very particular sort of) distinctiveness in order to access legal privileges. ${ }^{268}$

Such a political categorization rendered Indian tribes quite distinct from racial groups, as "nations" remain valid sites for social identification in a way race has not. ${ }^{269}$ Federal policy towards Indian tribes since the Nixon administration has emphasized respecting Indian political autonomy and their right to communal selfgovernance free of outside interference. ${ }^{270}$ As strict scrutiny began to monopolize race's legal playing field, the "political" nature of Indian status became the crucial distinction enabling "Indian-conscious" programs to survive. ${ }^{271}$ And the primary locus of political struggle for Native Americans has not been to be seen as "not Indian" but rather to have their own conception of Indianness given legal weight and meaning. ${ }^{272}$

Noting the doctrinal vitality of government noticing religion and indigenous status is not to say there is universal agreement in either of these two contexts. People do defend a "religion-blind" conception of public life, ${ }^{273}$ and likewise the seemingly exceptional treatment of Native Americans compared to the norm established by

268. See, e.g., Mashpee Tribe v. Town of Mashpee, 447 F. Supp. 940, 950 (D. Mass. 1978) (rejecting land claims by Mashpee Indians on grounds that they were not a "tribe" at the time of the suit), aff'd sub nom. Mashpee Tribe v. New Seabury Corp., 592 F.2d 575 (1st Cir. 1979). In an earlier proceeding, the District Court adopted a definition of "tribe" that was reliant on the Native American group's cohesive distinctiveness: "a body of Indians of the same or a similar race, united in a community under one leadership or government, and inhabiting a particular though sometimes ill-defined territory ...." Mashpee Tribe v. New Seabury Corp., 427 F. Supp. 899, 903 (D. Mass 1977) (quoting Montoya v. United States, 180 U.S. 261, 266 (1901)).

269. See Addie C. Rolnick, The Promise of Mancari: Indian Political Rights as Racial Remedy, 86 N.Y.U. L. REV. 958, 1028 (2011) (observing that Indians' categorization as a political community has enabled programs benefitting them to survive while other raceconscious proceedings have faltered).

270. Special Message to the Congress on Indian Affairs, PuB. PAPERS 564, 565 (July 8, 1970) (directing Congress to "create the conditions for a new era in which the Indian future is determined by Indian acts and Indian decisions").

271. See Stuart Minor Benjamin, Equal Protection and the Special Relationship: The Case of Native Hawaiians, 106 YALE L.J. 537, 568 (1996) (arguing that after Croson and Adarand, strict scrutiny must apply to Indian classifications not tied to a formal tribal relationship).

272. See Martha Minow, Identities, 3 Yale J.L. \& Human. 97, 114 (1991) (documenting the Mashpee Indians' ultimately futile effort to convince courts to recognize their particular mode of communal self-identification as members in a cohesive tribal body).

273. Philip Kurland proposed a religion-clause doctrine whereby "government cannot utilize religion as a standard for action or inaction because these clauses ... prohibit classification in terms of religion either to confer a benefit or to impose a burden." PHILIP B. KuRLAND, Religion and the Law: Of Church And State and the Supreme Court 112 (1962). Over fifteen years later, Kurland wryly reflected that the principle had been "met with almost uniform rejection" in all quarters. Philip B. Kurland, The Irrelevance of the Constitution: The Religion Clauses of the First Amendment and the Supreme Court, 24 VILL. L. REv. 3, 24 (1978). If Professor Kurland had exhibited a little more patience, he would have seen at least partial vindication of his stance in Employment Division v. Smith, which denied that the Free Exercise clause mandated exemptions for religious conduct from generally applicable laws. 494 U.S. 872, 890 (1990). 
current equal protection jurisprudence has also been opposed in some quarters. ${ }^{274} \mathrm{But}$ it is fair to say that in both cases, a mechanism for transcending a divisive past that does not rely on simply suppressing the offending identity is at least part of the mainstream conversation. If the problem is delineating groups by a hierarchy of privilege and subordination, one solution is simply to try and obliterate the group identities in question. But another is to pursue a vision of equality where citizens do not leverage group difference into a basis for social oppression.

\section{Transcending Racial Fear}

Religion and indigenous status both provide a model for how historically fraught identities can be utilized while nonetheless moving us "beyond" their dangerous pasts. For race, however, this move is considerably more controversial. Still, there is no reason to think that race will be implacably resistant to this sort of cultural reframing. Racial identity exists and is important to many. The task of turning it from something that is solely associated with misery and oppression into something that can be safely celebrated and appreciated may be difficult, but it is not impossible.

As Iris Marion Young observes, one of the great missed predictions of the modern era has been the assumption that the extension of formal equal rights would lead to a decline in persons identifying with particular groups. ${ }^{275}$ This, to put it mildly, has not been the case. ${ }^{276} \mathrm{~A}$ history of social differentiation creates significant group differences-linguistic, cultural, political, and otherwise - and it is no easy thing to wipe the slate clean. ${ }^{277}$ More to the point, it is unclear that we would always want to - at least with respect to distinctions that are not intrinsically related to differences in material outcomes or access to opportunity. The historical processes by which identities are formed are often tragic, but that does not mean that they create nothing of worth. It is often quite important to people who are members of social groups with long histories of oppression that they commemorate, even celebrate, how their ancestors persevered and created meaningful lives through adversity. ${ }^{278}$ These identities have value and can be worth preserving even if their creation came in the teeth

274. See, e.g., Robert Yazzie, "Watch Your Six”: An Indian Nation Judge's View of 25 Years of Indian Law, Where We Are and Where We Are Going, 23 AM. INDIAN L. REv. 497, 498 (1999) (recounting a Justice Department official's position that "all Indian legislation is unconstitutional because it is race-based").

275. YounG, supra note 9, at 163 ("Contrary to the assumption of modernization theory, increased urbanization and the extension of equal formal rights to all groups has not led to a decline in particularist affiliations.").

276. See generally Benjamin R. BARber, Jihad vs. McWorld (1996); AMy ChuA, World on Fire: How Exporting Free Market Democracy Breeds Ethnic Hatred and Global Instability (2003); Thomas L. Friedman, The LeXus AND the Olive Tree (rev. ed. 2000).

277. See Young, supra note 9, at 164 ("[I]n part because they have been segregated from one another, and in part because they have particular histories and traditions, there are cultural differences among social groups - differences in language, style of living, body comportment and gestures, values, and perspectives on society.").

278. The Jewish celebration of Passover is a clear example of this - the objective of Passover is not to forget Jews were ever slaves, but to remember it and remember how that experience forged Jews as a community. See Shoshana Silberman, A FAmily Haggadah II 20 (1997) ("This night is different from all other nights because once we were slaves to 
of the very sort of prejudice we all are trying to transcend. "Pasts we inherit affect who we become."279

Race, in particular, has developed a cultural resonance that renders it more than mere phenotype. Richard Ford argues that Justice Powell's "difference splitting" opinion in Bakke - permitting affirmative action insofar as it was in pursuit of diversity-"altered the incentives surrounding racial identity and thereby altered performance of racial identity." 280 Consequently, the cultural identity of a racial minority replaced a conceptualization of race dominated by a history of experiencing racism. ${ }^{281}$ In this formulation, race begins to approximate religion in terms of how its membership understands its affiliation with the identity axis. ${ }^{282}$ I would dispute both that the cultural conception of race was birthed by Bakke, ${ }^{283}$ as well as that the experience of racist domination cannot itself help forge a cultural identity. ${ }^{284}$ But insofar as racial identity possesses religion-like characteristics, it stands to reason that many people will value their racial identities and want them (sometimes) recognized the same as government (sometimes) recognizes religious identities.

I noted towards the beginning that the relationship between post-racialism and colorblindness is more complicated than is typically recognized and that one can imagine ways of transcending race that do not rely on ignoring the way race is inscribed in our daily lives. ${ }^{285}$ Lani Guinier writes:

My view is that it is premature to deny those [racial] differences when they are so important to so many people. That is not to say that you want ultimately to reinforce those differences as our goal or as our vision. But it does mean that if you are going to get people to the point where they

Pharoah in Egypt, but Adonai, our God, took us out with a mighty hand and an outstretched arm."). Recently, a considerable amount of Jewish theology has sought to explicitly incorporate the Holocaust into the collective meaning of what it is to be Jewish. See, e.g., EMIL L. FACKenheim, To Mend the World: Foundations of Future Jewish Thought 10 (1982) (arguing that the Holocaust created a "614th Commandment" for Jews: to not give Hitler "posthumous victories"); EliE WIESEL, The Trial of GOD (Marion Wiesel trans., Schocken Books Inc. 1995) (1979) (presenting a play in which Jewish villagers place God on trial for crimes committed against them). But see Avraham Burg, The Holocaust Is Over; We MuST RISE FROM ITS ASHES (2008) (arguing that excessive focus on the Holocaust has drastically limited the development of the Jewish people).

279. Claudia Card, Gender and Moral Luck, in Justice And CARE: Essential Readings in Feminist Ethics 79, 79 (Virginia Held ed., 1995).

280. Richard T. Ford, Beyond "Difference": A Reluctant Critique of Legal Identity Politics, in Left Legalism / LefT CRITIQue 38, 46 (Wendy Brown \& Janet Halley eds., 2002).

281. Id.

282. Meyler, supra note 258, at 293.

283. See Lawrence W. Levine, Black Culture and Black Consciousness: AfroAMERICAN FolK ThOught FROM SLAVERY TO FrEedom (30th anniversary ed. 2007) (documenting Black cultural traditions originating as early as the slave era).

284. See supra note 278 and accompanying text (detailing the effect that sustained marginalization and oppression had on the formation of Jewish identity); $c f$. IRIS MARION YOUNG, INCLUSION AND DEMOCRACY 136-45 (2000) (explaining how different groups possess different "perspectives" which condition but do not determine the way their members create and understand social meaning).

285. See supra notes 3-16 and accompanying text. 
can converse together and communicate across these differences, the first thing that you have to do is respect and recognize those differences. And having respected and recognized those differences, in my experience, you will find that people are much more willing to engage in conversation about the common good and about our common interests because their differences don't become so key to their self-definition. You have already recognized and respected those differences, so every conversation doesn't have to be about those differences which you've already recognized and respected. It's a way of transcending race ultimately. But in order get there, you must first recognize race. ${ }^{286}$

Race remains an important locus of identity for many people. Recognizing and respecting that is the first step in rendering it something that is not the focus of every political discussion. And in that way, race becomes normalized and familiar-the sort of identity we have ample experience in mediating and managing so it does not instill so much fear and anxiety within the polity.

Obviously, racial minorities want to "get beyond" a world in which they are at risk of systematic discrimination, oppression, and marginalization; just as Jews do not want to worry about being victimized by another Holocaust, just as Native Americans do not want to feel on the cusp of a new Trail of Tears. ${ }^{287}$ And because all people, the relatively advantaged included, are concerned about being just and fair to persons of diverse backgrounds, racial majorities often care quite a lot about not living in that world as well. ${ }^{288}$ But this concern is very separate from saying that race, or religion, or indigenous status, must be thrown away by virtue of its association with these evils. Post-racialism, stripped to the essence, should be about transcending racial oppression, not the cultural existence of race. If race could be rendered something akin to (an idealized vision of) religion in liberal societies - an identity that people possess, that people are proud of, that is flexible enough to adapt to their own preferences and outlooks, and that can be talked about and deliberated over without worrying about recreating conditions of domination and misery - that would be a massive moral victory and psychological break from our precarious status quo. ${ }^{289}$

286. Lani Guinier, More Democracy, 1995 U. CHI. LEGAL F. 1, 20 (emphasis added).

287. The use of these examples, of course, should not be taken to imply that racism, or anti-Semitism, or oppression of indigenous peoples is solely expressible through its most extreme, genocidal form. Indeed, I have argued that presenting discrimination solely in its most "serious" forms is often a mechanism for deflating and delegitimizing discrimination claims that do not seem to possess the extraordinary moral gravity of enslavement or ethnic cleansing. David Schraub, Playing with Cards: Discrimination Claims and the Charge of Bad Faith, 42 SOC. THEORY \& PRAC. 285, 290-92 (2016).

288. See Judith H. Katz, White Awareness: Handbook for Anti-Racism Training 13 (2d ed. 2003) ("Racism has been diagnosed as a form of schizophrenia in that there is a large gap between what whites believe and what we actually practice, which causes us to live in a state of psychological stress." (citations omitted)); Margo J. Monteith \& Gina L. Walters, Egalitarianism, Moral Obligation, and Prejudice-Related Personal Standards, 24 PeRSONAlity \& Soc. Psychol. Bull. 186, 195 (1998) (finding that even highly prejudiced individuals experience a significant moral compulsion urging them to temper their prejudice).

289. This applies to White people as well. See Flagg, supra note 253, at 957 (promoting 
Because this vision of post-racialism is not hostile to the mere recognition of race, it would not suffer from the inherent tension between the orthodox post-racial ambition of eliminating race altogether and strict scrutiny's elevation of it to hypersalience. ${ }^{290}$ People organize and associate along all sorts of axes, most of which are seen as unexceptional levers of normal political action. ${ }^{291}$ The vast majority of identities we hold are "noticed" by law at certain points and ignored at others. And so, like other race-conscious procedures, it would remain perfectly sensible to apply strict scrutiny in discrete areas where the use of race appears to be particularly pernicious or offensive to our normative commitments respecting racial equality. ${ }^{292}$ Law's intersection with culture is rarely governed by hard-and-fast rules. We sometimes want law to intervene to enable social or cultural choices that otherwise would be closed to us, and we sometimes want law to step back and leave us alone. Race is abnormal insofar as it is denied this flexibility; it is seen instead as something that must be hermetically sealed off from politics. ${ }^{293}$ A post-racial world would be one in which this aberration has been healed.

\section{CONCLUSION}

Strict scrutiny has a role to play in securing racial justice. But its connection to "post-racialism" is far more complicated than is typically acknowledged. It is an unstated assumption of American constitutional law that, while other race-specific political and legal programs ought to disappear with time, strict scrutiny can exist in perpetuity with no measurable effect on the course of American race relations.

This assumption cannot hold. Strict scrutiny elevates race to an exceptional role in American law, one which effectively guarantees we will not "get beyond" race. Moreover, unlike other race-conscious remedies, the Supreme Court does not seem to have placed any temporal limit on the use of strict scrutiny-rendering it the

the development of a "positive white racial identity, one neither founded on the implicit acceptance of white racial domination nor productive of distributive effects that systematically advantage whites").

290. See supra Parts II.A-B.

291. Bd. of Educ. of Kiryas Joel Vill. Sch. Dist. v. Grumet, 512 U.S. 687, 735 (1994) (Scalia, J., dissenting) ("The history of the populating of North America is in no small measure the story of groups of people sharing a common religious and cultural heritage striking out to form their own communities."); James U. Blacksher, Majority Black Districts, Kiryas Joel, and other Challenges to American Nationalism, 26 CuMB. L. REv. 407, 413 (1996) (noting "the high priority communal freedom of association enjoys in American social, political, and constitutional tradition," which renders it confusing "why political association by racial and religious groups should be regarded with such deep suspicion in constitutional jurisprudence").

292. As Charles R. Lawrence III observes, there is no way to justify any sort of constitutional doctrine respecting race relations without an underlying substantive commitment to the principle that certain groups cannot be subjected to social subordination. Charles R. Lawrence III, Forbidden Conversations: On Race, Privacy, and Community (A Continuing Conversation with John Ely on Racism and Democracy), 114 YALE L.J. 1353, 1382-84 (2005).

293. Cf. Rolnick, supra note 269, at 1036-41 (arguing that American Indian jurisprudence is unique in its antiracist implications because it recognizes and protects the political distinctiveness of Native American tribes). 
epitome of one "that [is] ageless in [its] reach into the past, and timeless in [its] ability to affect the future." ${ }^{294}$ One can imagine a racial jurisprudence that is informed by post-racial ambitions, but it is one that looks very little like modern strict scrutiny doctrine. ${ }^{295}$

One response to this problem is to concede that race is never something we will get beyond. The risk of racial strife and discord is, and will always be, too high to permit its usage by public actors. Intellectually, this position is perfectly coherent; but it carries with it a grave sacrifice - a world which is never post-racial, where race is always lurking as a menacing threat to the social order. ${ }^{296}$ But there is an alternative. We can reimagine "post-racialism" to bring race in line with other historically dangerous identities, such as religion or indigenous status. In both of these contexts, it is understood that getting beyond historical conflict and chaos does not require massive public suppression of the relevant identity. A more nuanced approach is tolerated, one which - precisely by recognizing how these identities matter to their bearers - normalizes them and helps begin the difficult but necessary process of transitioning them back into ordinary politics. A post-racial world, in this view, is not one in which race disappears, but where race can, if we choose, be part of how we identify and organize ourselves without fear that it will always and inexorably lead to ruination.

294. Wygant v. Jackson Bd. of Educ., 476 U.S. 267, 276 (1986).

295. See supra Part II.A.

296. See supra Part II.B. 